\title{
Observations of tephra fall impacts from the 2011 Shinmoedake eruption, Japan
}

\author{
Christina Magill ${ }^{1}$, Thomas Wilson ${ }^{2}$, and Tetsuya Okada ${ }^{1}$ \\ ${ }^{1}$ Risk Frontiers, Macquarie University, NSW 2109, Australia \\ ${ }^{2}$ Department of Geological Sciences, Centre for Risk, Resilience and Renewal, University of Canterbury, \\ Private Bag 4800, Christchurch, New Zealand
}

(Received November 7, 2012; Revised May 16, 2013; Accepted May 19, 2013; Online published July 8, 2013)

\begin{abstract}
The 2011 eruption of Shinmoedake, Japan, deposited tephra across Miyazaki prefecture impacting both urban and rural environments. We provide an overview of the impacts, management and recovery of a modern city, infrastructure networks and a diverse agricultural region following this moderate sized explosive eruption, focusing on four key sectors. Cleanup of tephra was time consuming, physically demanding and costly for residents, businesses and municipal authorities. The agricultural sector sustained large initial impacts with smothering, loading and abrasion of crops, soils and greenhouses. However, extreme concerns at the time of the eruption were not realised, with farming operations experiencing limited long-term effects. There were few disruptions to electrical networks due to resilient insulator design, a successful cleaning program, relatively coarse tephra and dry conditions. Cancellations and delays occurred on three rail lines resulting primarily from mechanical failure of track switches and loss of electrical contact between train wheels and tracks. Both residents and organisations exhibited high levels of adaptive capacity in response to the event and utilised regional and national networks to obtain information on past events and recovery strategies. The combination of relatively short eruption duration, well resourced and coordinated organisations and resilient infrastructure networks contributed to a strong recovery.
\end{abstract}

Key words: Eruption, impacts, Kirishima, risk, Shinmoedake, tephra, volcanic ash, volcanic hazards.

\section{Introduction}

Effective volcanic risk management requires having a robust knowledge of the likely impacts of individual hazards. Impact assessment approaches in volcanology (e.g. Blong and McKee, 1995; Wilson et al., 2007, 2012a; Jenkins et al., 2013) mirror those in other hazard disciplines (e.g. earthquake, tsunami, etc.), which rely on relatively short (several days to weeks) post-event on-site assessments, which aim to observe impacts and/or document the effectiveness of mitigation measures and crisis management strategies; see FEMA (2006), Boughton et al. (2011), Cubrinovski et al. (2011), EERI (2011), Spence et al. (2011), Architectural Institute of Japan (2012) and Bird et al. (2013), as examples. This has been an effective way to begin building a body of evidence detailing volcanic impacts on human activities across different eruption magnitudes, durations and styles in varying climates and ecosystems. Each new eruption represents an opportunity to add to the global knowledge base through analysing eruption characteristics and corresponding effects to the local environment and human activities.

The 2011 eruption of Shinmoedake volcano, Kyushu Island, offered an opportunity to observe the impacts, management and short-term recovery of a moderate-sized tephra

Copyright (c) The Society of Geomagnetism and Earth, Planetary and Space Sciences (SGEPSS); The Seismological Society of Japan; The Volcanological Society of Japan; The Geodetic Society of Japan; The Japanese Society for Planetary Sciences; TERRAPUB.

doi: 10.5047/eps.2013.05.010 fall event on both a modern city and a diverse, densely populated agricultural region in southern Japan. Beginning on 19 January 2011, the eruption produced an eruption plume that deposited tephra predominantly to the southeast affecting ten municipalities, including Miyakonojo City, Takaharu Town, Mimata Town and Nichinan City (Fig. 1). The agricultural areas of Miike ( $\sim 7 \mathrm{~km}$ from vent) and Yamada ( $\sim 17 \mathrm{~km}$ from vent), both within Miyakonojo City, were significantly affected by heavy tephra falls.

Previous studies highlight that agriculture, the built environment, critical infrastructure networks, transport networks and human health are commonly affected during a tephra fall event and often require the most management support (Blong, 1984; Johnston et al., 2000; Horwell and Baxter, 2006; Wilson et al., 2011, 2012a; Bird and Gísladóttir, 2012). Impacts are typically interdependent across a range of sectors, requiring a holistic and integrated management response (Johnston et al., 2000; Wilson et al., 2012b). Assessing vulnerability to tephra fall is more complex than simply relating thickness or mass loading to the degree of impact; the duration and timing of an event, along with other attributes such as grain size, mineralogy and soluble acidic salt content, are all important controls (e.g. Cook et al., 1981; Folsom, 1986; Cronin et al., 1998, 2003; Witham et al., 2005; Wilson et al., 2011, 2012b). Of equal importance is the resilience of the community, organisation or unit, in relation to economic, environmental, social and political variables (Reycraft and Bawden, 2000; Haynes 


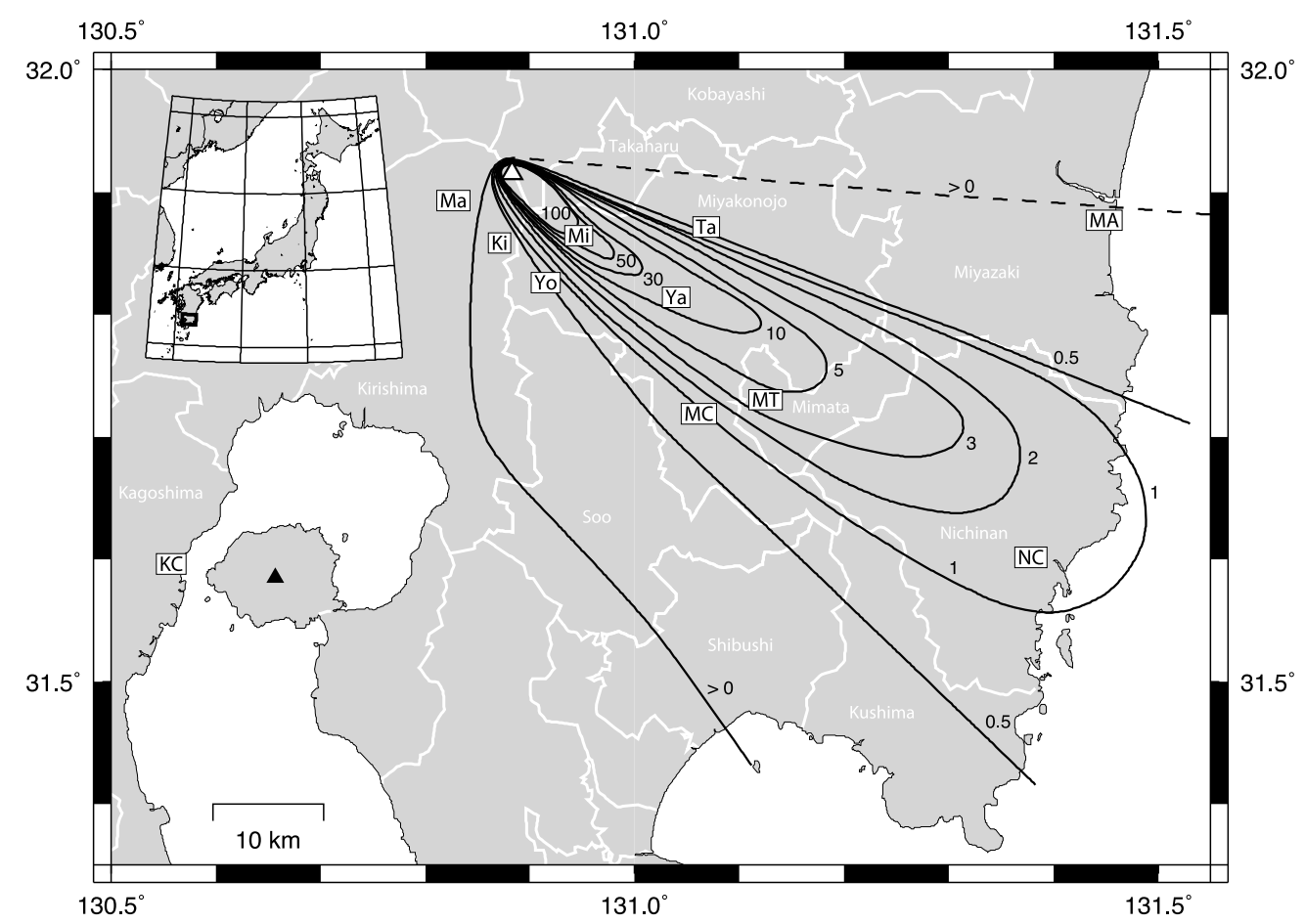

Fig. 1. Area impacted by tephra falls from the 2011 Shinmoedake eruption. Isomass contours are in $\mathrm{kg} / \mathrm{m}^{2}$ and describe tephra accumulation prior to 28th January (AIST, 2011). Municipality boundaries are in white. Letters in boxes refer to place names mentioned in the text: KC Kagoshima City Hall (central Kagoshima), Ki Kirishima, Ma Makizono, MA Miyazaki Airport, MC Miyakonojo City Hall (central Miyakonojo), Mi Miike, MT Mimata Town Hall (central Mimata), NC Nichinan City Hall (central Nichinan), Ta Takazaki, Ya Yamada and Yo Yoshinomoto. White triangle Shinmoedake volcano and black triangle Sakurajima volcano.

et al., 2008; Bird and Gísladóttir, 2012). The interaction of all these factors collectively determines the socio-economic loss and disruption (Ort et al., 2008).

Our aims in this study were to assess the impacts of tephra fall to exposed communities during the 2011 Shinmoedake eruption and to discuss with those directly involved the management of these impacts. We focused on understanding tephra fall impacts to individual system components but also considered overall system functionality. These aims were designed to capture lessons from the experience that might inform the future management of tephra falls in the region and in other municipalities exposed to similar hazards. The manuscript presents an overview of the eruption focusing on tephra producing phases, analyses areas exposed to tephra fall, and documents impacts and management strategies. We focus on four key sectors identified as significant during this particular eruption: tephra cleanup operations, agriculture, electric power systems and the rail network.

\section{2011 Shinmoedake Eruption}

Shinmoedake volcano stands on the boundary of Kagoshima and Miyazaki Prefectures and is the most recently active eruptive centre in the Kirishima volcanic complex (Imura and Kobayashi, 1991; Imura, 1992). The complex includes more than twenty small Quaternary centres that form a composite volcano covering an area of approximately $20 \times 30 \mathrm{~km}^{2}$ (Imura, 1992; Imura and Kobayashi, 2001). Prior to 2011, the most recent significant eruption (bulk volume $0.21 \mathrm{~km}^{3}$ ) from the Kirishima complex occurred between 1716 and 1717; magmatic eruptions with volumes less than $0.01 \mathrm{~km}^{3}$ then occurred in 1771-1772 and 1822 (Imura and Kobayashi, 1991; Imura, 1992). Small phreatic eruptions occurred in 1959, 1991 and 2008 (Imura and Kobayashi, 2001; Miyabuchi et al., 2013).

After a period of inflation, the 2011 eruption began with a phreatomagmatic explosion on 19 January, which was then followed by a small tephra explosion on 22 January. Most tephra was deposited as the result of Subplinian explosions on 26 and 27 January, generating plumes up to $8.5 \mathrm{~km}$ that travelled southeast of the vent. Tephra was erupted continuously until 30 January and regular plumes were observed into March. The last tephra plume was observed on 7 September 2011 (Siebert and Simkin, 2002-, with information collated from the Earthquake Research Institute, University of Tokyo (ERI); Geographical Survey of Japan (GSI); Japan Meteorological Agency (JMA); and Tokyo Volcanic Ash Advisory Centre (VAAC); Hasenaka et al., 2011; Miyabuchi et al., 2013).

In this manuscript we will focus on the impacts observed as the result of tephra accumulation during the main fallout phase of the eruption; additional consequences are summarised in Table 1. A $2 \mathrm{~km}$ exclusion zone was put in place at the onset of the eruption, which was increased to $3 \mathrm{~km}$ on 31 January 2011. Considerable impacts to business revenue were reported within and near to the exclusion zone, where there is a thriving tourist hot springs industry. Tourist numbers remained low 9 months after the eruption, with many perceiving the area to be unsafe. Several thousand people in Miyakonojo and Takaharu evacuated for short periods of days to weeks, mostly from areas exposed to potential lahars. 
Table 1. Summary of non-tephra fall impacts during the Shinmoedake eruption.

\begin{tabular}{|c|c|}
\hline Hazard & Details \\
\hline \multirow[t]{5}{*}{ Clast fallout } & 27 January: Large clasts (4-6 cm diameter) cracked car windows in Miike, $7 \mathrm{~km}$ from the vent. \\
\hline & 14 February: $1.5-2 \mathrm{~cm}$ diameter scoria clasts caused damage in Kobayashi City (14 km from vent), \\
\hline & including breakage of solar panels and car windows and holes in plastic corrugated roofing. \\
\hline & As at 7 March there were 696 reported cases of damage in Kobayashi City. \\
\hline & 27 January-18 April: 32 recorded cases of solar panel and car window damage in Takaharu Town. \\
\hline \multirow[t]{8}{*}{ Shockwaves } & 1 February: An estimated 381 panes of glass were broken in 99 schools, hotels and houses \\
\hline & in the Makizono and Kirishima areas of Kirishima City. Some of these windows were wire-reinforced \\
\hline & and damage was not restricted to windows facing the volcano. Damage occurred up to $12 \mathrm{~km}$ \\
\hline & from the vent. Window and doorframes were also bent. \\
\hline & 2 February: Shockwaves from two explosive eruptions broke windows in Yoshinomoto, Miyakonojo City, \\
\hline & and in Kirishima (one person injured, see Table 7). \\
\hline & A total of 215 buildings in Kirishima City reported cases of glass breakage (as at $7 \mathrm{March}$ ). There were \\
\hline & also isolated reports of bending of automatic door tracks and damage to light fittings. \\
\hline \multirow[t]{4}{*}{ Lahars } & 17 February: A storm event prompted evacuation advisories for 2,523 residents (1,148 households) \\
\hline & in Miyakonojo City and 214 residents (99 households) in Takaharu Town. \\
\hline & Catchments in Takaharu Town filled with pyroclastic debris, leading authorities to undertake \\
\hline & 24 catchment clearing operations between mid-February and September. \\
\hline
\end{tabular}

Sources: Cabinet Office (2011); Fukuoka District Meteorological Observatory Volcano Monitoring and Information Centre and Kagoshima Regional Meteorological Observatory (2011); Kagoshima Regional Meteorological Observatory (2011); Takaharu Town (2011a); Miyazaki Nichinichi Shimbun, 2 February 2011; Asahi Shimbun and Minaminippon Shimbun, 2 February 2011; Siebert and Simkin (2002-).

We have not considered impacts to the aviation sector in depth within this manuscript. However, Tokyo VAAC issued 140 advisories between January and March 2011 based on regular tephra plumes observed by pilots and satellite imagery. This reduced to 14 advisories between April and July. Miyazaki Airport was closed at various times throughout the eruptive activity, causing the cancelation and rerouting of flights. This contributed to $22 \%$ fewer passengers than the previous year, on domestic flights entering or exiting this airport between 26 January and 10 March (prior to the Tohoku Earthquake) (Miyazaki Airport Building Co. Ltd., 2011).

\section{Study Area}

Miyakonojo City is the second largest city in Miyazaki Prefecture with an area of $653 \mathrm{~km}^{2}$ and approximately 170 thousand residents (City of Miyakonojo, 2013). The city centre, positioned approximately $27 \mathrm{~km} \mathrm{SE}$ of the vent, received an estimated $1 \mathrm{~kg} / \mathrm{m}^{2}$ of tephra (Fig. 1). Takaharu Town centre (12 km E of the vent) was spared large accummulations of tephra with only $0-0.5 \mathrm{~kg} / \mathrm{m}^{2}$ reported in inhabited areas. Mimata Town centre (30 km SE of the vent) and Nicihinan City centre (58 km SE of the vent) received an estimated $3-5 \mathrm{~kg} / \mathrm{m}^{2}$ and $1-2 \mathrm{~kg} / \mathrm{m}^{2}$ respectively.

Miyazaki Prefecture is one of the largest livestock producers in Japan, with total agriculture production in 2008 estimated at 324,600 million JPY $(\sim 4.2$ billion USD as at January 2011). Of this value, $41 \%$ was attributed to 'cultivated production', $48 \%$ to 'livestock production' and $1 \%$ to 'processed agriculture' (Ministry of Agriculture, Forestry and Fisheries, 2010). Farm size generally increases with elevation above sea level and, as topography steepens inland, production switches to a higher proportion of livestock feedlot farming, predominantly pigs, poultry and beef cows. Farms are typically small ( $<10$ ha) and achieve high intensity production. Lowland areas are dominated by crop production, especially rice and tea; ground and root vegetables as well as tree crops. The use of greenhouses for further intensification of production is widespread. Double and even triple cropping occurs in some areas throughout the year with relatively warm, moist (rainfall: 2,580 mm/year), sub-tropical (latitude $31^{\circ} \mathrm{N}$ ) conditions (JMA, 2012). Many households have small landholdings to supplement income, with only $25 \%$ of 50,735 farmers stating their main business as agriculture (2005 census data; Miyazaki Prefecture, 2010). More than half the agricultural workforce is older than 60 years $(51.5 \%$ in Miyazaki prefecture) (Miyazaki Prefecture, 2010).

\section{Methodology}

In this study, the authors made two visits to the tephraaffected area. The first, between 28 January and 3 February 2011 , corresponded with the end of the major tephra deposition phase and when residents, businesses and local governments were assessing impacts and beginning cleanup (Magill and Okada, 2011). At this time, there was still a great deal of uncertainty and concern over potential continuation of volcanic activity. The second visit was in midNovember 2011, nine months after the peak of the eruption crisis, and provided the opportunity to observe fully manifested impacts, examine the short-term recovery and discuss the effectiveness of management decisions with relevant stakeholders. The two field visits were beneficial in understanding emerging impacts, identifying relative stress points and in building relationships with affected stakeholders.

Research methods for the first field investigation included tephra collection and semi-structured interviews with residents, business owners, farmers and agricultural organisations. Semi-structured interviews with stakeholders, in- 
cluding critical infrastructure, agriculture and emergency management organisations, took place during the second visit. At this time, participants could give a more reflective view of issues while not having to deal with the immediate crisis. Interview questions were adapted to be relevant for each participant, but typically followed: impacts experienced; cleanup requirements; immediate mitigation strategies and their effectiveness; the effectiveness of emergency management plans and any subsequent adaptations since the eruption; interdependency with other systems, organisations or sectors; and the recovery process. The interview format allowed free exploration and discussion around the various topics that had been touched upon in question responses. All participants we spoke to were eager to pass on their experiences. Interviews were conducted by three researchers, one being fluent in both Japanese and English who also acted as translator, and responses recorded by notation. Interviews were reviewed daily by the research team to ensure accuracy. We have remained in contact with those interviewed since and remain grateful for additional information provided.

While focusing on the four sectors of cleanup, agriculture, electric power systems and the rail network, we attempt to combine our findings with measures of exposure to tephra fall. In this way, by relating consequences to hazard magnitude, we may help to better inform future risk analyses. In doing this, we consider only the major tephra deposition phase. Although eruptive activity continued after this period, tephra accumulation to the southeast and northeast was small and did not contribute greatly to observed impacts.

\section{Exposure Analysis}

To consider the land-use types impacted by the eruption, a recent cloud-free Landsat 5 image (Scene ID: LT51120382009300BJC00; acquired on 2009-10-27) covering the study area was downloaded through the U.S. Geological Survey Global Visualization Viewer. It contained all six multi-spectral bands at $30 \mathrm{~m}$-resolution. Next, a standard, supervised image classification approach (i.e. Maximum Likelihood Classifier) was employed to classify two major land covers of interest: agricultural land and settlement (urban) areas. Two post-processing steps (i.e. filtering and masking) were used against the high-resolution base imagery on Google Earth in order to improve the overall accuracy of land cover determinations. OpenStreetMap road maps and classifications were downloaded from CloudMade; three train lines that intersected the tephra footprint were digitised from Bing aerial imagery and simplified electricity transmission lines were digitised from information provided by Kyushu Electric Power Company (KEPC).

Tephra isomass contours produced by AIST (2011) were then overlaid so that land-use, road, electricity and rail exposure could be estimated (Fig. 2; Tables 2-6). Total land areas impacted for each municipality are summarised in Table 2 and the agricultural, urban and total land areas impacted within each municipality are shown in Table 3 . It must be noted that in some regional areas, such as Takaharu Town, information is only available for national and prefectural roads. Therefore, the total road length estimated (6880 $\mathrm{km}$ ) is a lower bound estimate (Table 4). Also, distances given for the electricity network are approximate only as calculations were based on a schematic diagram provided by KEPC (Fig. 2(d); Table 5). It was not possible to calculate the exposed lengths of distribution networks $<60 \mathrm{kV}$, but it can be assumed that hundreds of kilometres of low voltage circuits were affected.

\section{Impacts of Tephra}

In this section we focus on cleanup activities and impacts to agriculture, electric power systems and the rail network during the Shinmoedake eruption. We consider how residents and organisations managed these impacts and discuss the success of these actions. When considering cleanup we also make an attempt to quantify the costs, resources and time associated with these activities.

\subsection{Cleanup}

6.1.1 Situation during eruption Approximately 106 $\mathrm{km}^{2}$ of urban land experienced some degree of tephra fall (Table 3). From our observations and interviewee accounts, tephra needed to be removed from most urban areas, with particular attention made to clean the roofs of residential and commercial buildings, paved areas and roads. Fine tephra (ash) also contaminated the interior of buildings, requiring repeated cleaning. The cleanup was compounded by tephra being remobilised by wind and traffic.

Significantly, a total of 37 people were injured during the eruption with all but one injury sustained during tephra cleanup activities (Table 7). This is a common phenomena following tephra fall in urban environments, having been observed in Quito, Ecuador in 1999 and in Guatemala city, Guatemala in 2010 (Leonard et al., 2005; Wardman et al., 2012a).

Following the main period of tephra fall (26-27 January), the removal of tephra from major roads was prioritised by authorities to secure safe driving conditions. At various times during the eruption, sections of the Miyazaki expressway and several national and prefectural roads were closed or had lower speed limits implemented due to reduced visibility from falling and remobilised material. In areas such as Takaharu, local government prioritised maintaining functionality of roads that might have been required in the case of evacuation. To the best of our knowledge, there were no reported road accidents as the result of tephra deposition.

The sewage network in the affected area was well sealed and without cross connections, therefore eliminating significant tephra ingestion. There were some localised blockages of gutters and sediment traps due to clogging, but this was remedied quickly by cleaning operations (Miyakonojo City Office, personal communication November 2011). Roadside wastewater gutters also suffered some localised blocking but were easily cleaned by shovel and mechanised sweeper trucks. In homes, if pipes from roof gutters ran directly to underwater pipes then residents were advised to disconnect these. They were then left unconnected until heavy rain in October when all tephra was flushed from the system (Takaharu Town Office, personal communication November 2011). 

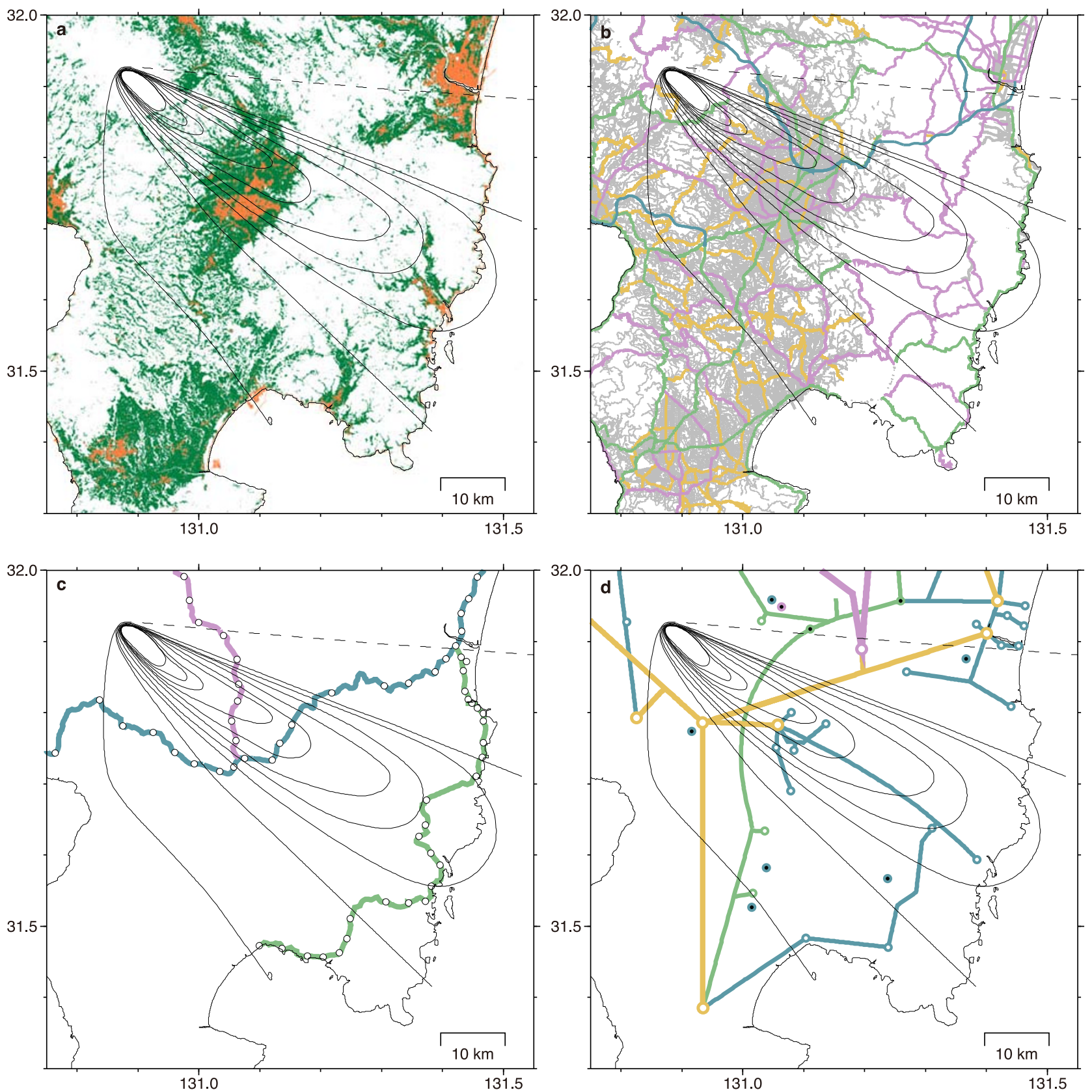

Fig. 2. Exposure maps created for (a) agricultural and urban land-usage (based on Landsat imagery); (b) road networks (OpenStreetMap); (c) rail lines (digitised from aerial imagery)—Kitto Line (pink), Nippo Mainline (blue) and Nichinan Line (green); and (d) electricity distribution (schematic, approximation of network provided by Kyushu Electric Power Company)—500 kV (pink), $220 \mathrm{kV}$ (yellow), $110 \mathrm{kV}$ (green) and $60 \mathrm{kV}$ (blue), white circles are transforming stations and black, hydro power plants. Isomass maps (AIST, 2011) shown in black have contour values equal to those in Fig. 1.

6.1.2 Management Prior to the eruption there were no specific plans for managing tephra cleanup efforts; however, local governments were well structured and individual department responsibilities were determined quickly. Within Miyakonojo City Government, the Department of General Affairs had overall responsibility for coordinating cleanup activities with departments such as road construction and procurement also involved.

Road maintenance staff from Miyakonojo City Government implemented four approaches for road cleanup, dependent on location and tephra accumulation. On major bypass roads where heavy traffic had moved tephra to the edges or where accumulation was small (i.e. less than sev- eral $\mathrm{kg} / \mathrm{m}^{2}$ ) then a single spray truck was used. In urban areas, where tephra was thicker, cleanup required a spray truck, road sweeper and dump trucks. Once tephra was removed the road was sprayed again with water to prevent remobilisation. The third approach was only employed in agricultural areas where accumulation was particularly large and simply involved using a front-end-loader to scoop tephra from roads. Finally, where necessary, narrow residential roads underwent manual cleaning with the use of shovels, brushes and push-sweepers. No specific thresholds were used for removing tephra from roads but if road markings were obscured then these roads were prioritised.

Beyond road cleanup, residents and businesses were re- 
Table 2. Total land area, tephra affected land area and percentage affected by municipality. Prefecture names are given in brackets.

\begin{tabular}{lccr}
\hline & Total land area $\left(\mathrm{km}^{2}\right)$ & Tephra affected area $\left(\mathrm{km}^{2}\right)$ & $\%$ tephra affected \\
\hline Miyakonojo City (Miyazaki) & 653.6 & 612.2 & 93.7 \\
Nichinan City (Miyazaki) & 536.9 & 536.9 & 100.0 \\
Miyazaki City (Miyazaki) & 644.9 & 326.9 & 50.7 \\
Soo City (Kagoshima) & 389.5 & 305.5 & 78.4 \\
Kushima City (Miyazaki) & 294.1 & 294.1 & 100.0 \\
Shibushi City (Kagoshima) & 288.7 & 217.6 & 75.4 \\
Mimata Town (Miyazaki) & 110.0 & 110.0 & 100.0 \\
Kirishima City (Kagoshima) & 603.7 & 107.3 & 17.8 \\
Takaharu Town (Miyazaki) & 86.3 & 36.8 & 42.6 \\
Kobayashi City (Miyazaki) & 474.6 & 11.5 & 2.4
\end{tabular}

Table 3. Agricultural (Ag), Urban (Ur) and Total (To) land areas ( $\mathrm{km}^{2}$ ) impacted by each level of tephra accumulation identified by AIST (2011) for each municipality. Total land areas affected for each municipality and accumulation range are in bold.

\begin{tabular}{|c|c|c|c|c|c|c|c|c|c|c|c|c|}
\hline \multicolumn{2}{|c|}{$\begin{array}{l}\text { Tephra accumu- } \\
\text { lation }\left(\mathrm{kg} / \mathrm{m}^{2}\right)\end{array}$} & \multirow{2}{*}{$\begin{array}{r}\text { Miyakonojo } \\
49.1\end{array}$} & \multirow{2}{*}{$\begin{array}{r}\text { Nichinan } \\
0.0\end{array}$} & \multirow{2}{*}{$\begin{array}{r}\text { Miyazaki } \\
65.9\end{array}$} & \multirow{2}{*}{$\frac{\text { Soo }}{86.7}$} & \multirow{2}{*}{$\begin{array}{r}\text { Kushima } \\
37.4\end{array}$} & \multirow{2}{*}{$\begin{array}{r}\text { Shibushi } \\
57.0\end{array}$} & \multirow{2}{*}{$\begin{array}{r}\text { Mimata } \\
0.0\end{array}$} & \multirow{2}{*}{$\begin{array}{r}\text { Kirishima } \\
9.3\end{array}$} & \multirow{2}{*}{$\begin{array}{r}\text { Takaharu } \\
8.7\end{array}$} & \multirow{2}{*}{$\begin{array}{r}\text { Kobayashi } \\
0.0\end{array}$} & \multirow{2}{*}{$\begin{array}{c}\text { Total } \\
314.0\end{array}$} \\
\hline $0-0.5$ & $\mathrm{Ag}$ & & & & & & & & & & & \\
\hline & $\mathrm{Ur}$ & 2.1 & 0.0 & 22.1 & 5.2 & 5.4 & 4.0 & 0.0 & 0.0 & 0.1 & 0.0 & 38.9 \\
\hline & To & 178.1 & 4.0 & 299.2 & 290.1 & 193.0 & 200.9 & 0.0 & 94.2 & 19.2 & 2.1 & 1280.8 \\
\hline \multirow[t]{3}{*}{$0.5-1$} & $\mathrm{Ag}$ & 32.0 & 16.5 & 0.5 & 4.8 & 10.4 & 0.1 & 0.0 & 0.0 & 0.8 & 0.0 & 65.2 \\
\hline & $\mathrm{Ur}$ & 9.6 & 12.6 & 0.0 & 0.3 & 0.4 & 0.0 & 0.0 & 0.0 & 0.0 & 0.0 & 22.9 \\
\hline & To & 111.4 & 106.3 & 12.7 & 15.3 & 97.1 & 16.8 & 0.1 & 1.8 & 3.4 & 0.7 & 365.6 \\
\hline \multirow[t]{3}{*}{$1-2$} & $\mathrm{Ag}$ & 16.2 & 34.5 & 0.5 & & 0.0 & & 2.3 & 0.0 & 0.2 & 0.0 & 53.7 \\
\hline & $\mathrm{Ur}$ & 7.0 & 9.4 & 0.0 & & 0.0 & & 0.1 & 0.0 & 0.0 & 0.0 & 16.5 \\
\hline & To & 51.8 & 264.2 & 13.7 & & 4.0 & & 12.4 & 2.7 & 1.0 & 0.4 & 350.3 \\
\hline \multirow[t]{3}{*}{$2-3$} & $\mathrm{Ag}$ & 13.3 & 4.5 & 0.0 & & & & 3.9 & 0.0 & 0.2 & 0.0 & 21.8 \\
\hline & $\mathrm{Ur}$ & 5.5 & 0.0 & 0.0 & & & & 0.8 & 0.0 & 0.0 & 0.0 & 6.3 \\
\hline & To & 50.6 & 113.6 & 1.3 & & & & 22.4 & 1.9 & 1.7 & 0.4 & 192 \\
\hline \multirow[t]{3}{*}{$3-5$} & $\mathrm{Ag}$ & 24.6 & 1.2 & & & & & 9.1 & 0.0 & 0.0 & 0.0 & 34.9 \\
\hline & $\mathrm{Ur}$ & 5.7 & 0.0 & & & & & 3.7 & 0.0 & 0.0 & 0.0 & 9.4 \\
\hline & To & 62.6 & 48.7 & & & & & 64.4 & 0.9 & 2.8 & 0.1 & 179.5 \\
\hline \multirow[t]{3}{*}{$5-10$} & $\mathrm{Ag}$ & 38.0 & & & & & & 6.6 & 0.0 & 0.0 & 0.0 & 44.6 \\
\hline & $\mathrm{Ur}$ & 8.1 & & & & & & 1.4 & 0.0 & 0.0 & 0.0 & 9.5 \\
\hline & To & 73.5 & & & & & & 10.7 & 0.6 & 1.9 & 0.2 & 86.9 \\
\hline \multirow[t]{3}{*}{$10-30$} & $\mathrm{Ag}$ & 26.3 & & & & & & & 0.0 & 0.0 & 0.0 & 26.3 \\
\hline & $\mathrm{Ur}$ & 2.3 & & & & & & & 0.0 & 0.0 & 0.0 & 2.3 \\
\hline & To & 56.7 & & & & & & & 0.5 & 1.8 & 0.2 & 59.1 \\
\hline \multirow[t]{3}{*}{$30-50$} & $\mathrm{Ag}$ & 1.9 & & & & & & & 0.0 & 0.0 & 0.0 & 1.9 \\
\hline & $\mathrm{Ur}$ & 0.0 & & & & & & & 0.0 & 0.0 & 0.0 & 0 \\
\hline & To & 13.0 & & & & & & & 0.4 & 1.0 & 0.2 & 14.6 \\
\hline \multirow[t]{3}{*}{ 50-100 } & $\mathrm{Ag}$ & 1.7 & & & & & & & 0.0 & 0.0 & 0.0 & 1.7 \\
\hline & $\mathrm{Ur}$ & 0.0 & & & & & & & 0.0 & 0.0 & 0.0 & 0 \\
\hline & To & 8.4 & & & & & & & 0.8 & 0.2 & 0.1 & 9.5 \\
\hline \multirow[t]{3}{*}{$>100$} & $\mathrm{Ag}$ & 0.0 & & & & & & & 0.0 & 0.0 & 0.0 & 0 \\
\hline & $\mathrm{Ur}$ & 0.0 & & & & & & & 0.0 & 0.0 & 0.0 & 0 \\
\hline & To & 5.9 & & & & & & & 3.5 & 3.7 & 7.2 & 20.3 \\
\hline \multirow[t]{3}{*}{ Total } & Ag & 203 & 56.7 & 66.9 & 91.4 & 47.8 & 57.1 & 21.9 & 9.3 & 10.0 & 0.0 & \\
\hline & Ur & 40.2 & 22.1 & 22.1 & 5.5 & 5.8 & 4.0 & 6.0 & 0.0 & 0.1 & 0.0 & \\
\hline & To & 612.2 & 536.9 & 327 & 305.5 & 294.1 & 217.6 & 110.0 & 107.3 & 36.8 & 11.5 & \\
\hline
\end{tabular}

sponsible for the cleanup and collection of tephra within their properties, although it was not until 30 January that residents in Miyakonojo were advised through news media that tephra would be collected as non-burnable rubbish. At this time residents were asked not to mix tephra with other rubbish or to wash it into drains. Businesses in Miyakonojo on the other hand were required to transport tephra to a tem- porary dumpsite in Yamada, approximately $12 \mathrm{~km}$ from the central business district. In Takaharu, residents and businesses were advised to drop tephra at one of 250 existing waste stations for compostable waste. The tephra was then collected from these central points and brought to a designated dumpsite. Tephra from roofs, grounds and carparks was typically collected in plastic bags and sacks, loaded 
Table 4. Approximate road lengths (km) impacted by various ranges of tephra accumulation (see Fig. 2(b)). Road maps and classifications from OpenStreetMap; isomass contours from AIST (2011).

\begin{tabular}{|c|c|c|c|c|c|c|c|c|}
\hline $\begin{array}{l}\text { Tephra accumu- } \\
\text { lation }\left(\mathrm{kg} / \mathrm{m}^{2}\right)\end{array}$ & motorway & trunk & primary & secondary & tertiary & urban & rural & all roads \\
\hline $0-0.5$ & 59.7 & 139.0 & 238.0 & 196.3 & 347.9 & 1354.9 & 1342.1 & 3678.0 \\
\hline $0.5-1$ & 3.2 & 65.9 & 68.2 & 19.7 & 63.0 & 259.5 & 257.2 & 736.9 \\
\hline $1-2$ & 4.7 & 35.9 & 87.8 & 7.7 & 53.3 & 119.9 & 171.6 & 480.8 \\
\hline $2-3$ & 6.8 & 11.6 & 28.8 & 9.7 & 36.2 & 127.7 & 157.0 & 377.9 \\
\hline $3-5$ & 16.7 & 12.6 & 42.3 & 11.4 & 59.3 & 271.5 & 238.7 & 652.5 \\
\hline $5-10$ & 16.1 & 17.1 & 21.0 & 9.8 & 101.3 & 170.3 & 241.8 & 577.4 \\
\hline $10-30$ & 9.5 & 6.2 & 21.0 & 10.0 & 30.6 & 89.8 & 149.6 & 316.7 \\
\hline $30-50$ & & 1.5 & 1.8 & 3.7 & 1.8 & 15.3 & 11.5 & 35.6 \\
\hline $50-100$ & & 3.0 & 2.0 & 0.7 & 0.2 & 12.2 & 4.3 & 22.3 \\
\hline$>100$ & & & & & & 2.0 & & 2.0 \\
\hline Total & 116.8 & 292.8 & 511.0 & 269.0 & 693.6 & 2423.1 & 2573.8 & 6880.1 \\
\hline
\end{tabular}

Table 5. Estimated exposure of Kyushu Electric Power Company network to tephra fall; see Fig. 2(b). Approximations of electricity lines given by KEPC and Isomass contours by AIST (2011).

\begin{tabular}{|c|c|c|c|c|c|c|}
\hline \multirow[b]{2}{*}{ Tephra load $\left(\mathrm{kg} / \mathrm{m}^{2}\right)$} & \multicolumn{4}{|c|}{ Approximated length $(\mathrm{km})$} & \multicolumn{2}{|c|}{ Facilities affected } \\
\hline & $500 \mathrm{kV}$ & $220 \mathrm{kV}$ & $110 \mathrm{kV}$ & $60 \mathrm{kV}$ & Hydro stations & Transforming stations \\
\hline $0-0.5$ & 3.4 & 59.3 & 28.3 & 44.6 & 3 & 8 \\
\hline $0.5-1$ & & 5.5 & 4.4 & 12.2 & 1 & 1 \\
\hline $1-2$ & & 3.3 & 1.3 & 16.2 & & 2 \\
\hline $2-3$ & & 4.6 & 1.8 & 10.9 & & 1 \\
\hline $3-5$ & & 4.9 & 2 & 16.6 & & 1 \\
\hline $5-10$ & & 5.2 & 2.4 & 21.2 & & 2 \\
\hline $10-30$ & & 5.5 & 4.3 & 1.5 & & 1 \\
\hline Total & 3.4 & 88.3 & 44.5 & 123.2 & 4 & 16 \\
\hline
\end{tabular}

Table 6. Estimated exposure of rail lines and stations to tephra fall; see Fig. 2(c). Lines and stations digitised from Bing aerial imagery and Isomass contours from AIST (2011).

\begin{tabular}{|c|c|c|c|c|c|c|}
\hline \multirow[b]{2}{*}{ Tephra load $\left(\mathrm{kg} / \mathrm{m}^{2}\right)$} & \multicolumn{2}{|c|}{ Kitto line } & \multicolumn{2}{|c|}{ Nichinan line } & \multicolumn{2}{|c|}{ Nippo line } \\
\hline & Length $(\mathrm{km})$ & Stations & Length $(\mathrm{km})$ & Stations & Length $(\mathrm{km})$ & Stations \\
\hline $0-0.5$ & 6.32 & 2 & 41.80 & 17 & 48.63 & 9 \\
\hline $0.5-1$ & 0.63 & 0 & 20.14 & 5 & 6.83 & 2 \\
\hline $1-2$ & 0.42 & 0 & 26.37 & 5 & 2.66 & 0 \\
\hline $2-3$ & 3.07 & 0 & & & 5.15 & 1 \\
\hline $3-5$ & 4.36 & 2 & & & 5.83 & 1 \\
\hline $5-10$ & 3.69 & 1 & & & 6.22 & 2 \\
\hline $10-30$ & 3.93 & 1 & & & & \\
\hline Total & 22.42 & 6 & 88.31 & 27 & 75.32 & 15 \\
\hline
\end{tabular}

Table 7. Casualties reported during the Shinmoedake eruption (Source: Cabinet Office, 2011, original data provided by Fire and Disaster Management Agency, correct as of 7 March 2011).

\begin{tabular}{|c|c|c|c|c|}
\hline \multirow[t]{2}{*}{ Location } & \multirow[t]{2}{*}{$\begin{array}{l}\text { Tephra accumulation } \\
\qquad\left(\mathrm{kg} / \mathrm{m}^{2}\right)\end{array}$} & \multirow[t]{2}{*}{ Description of Injury } & \multicolumn{2}{|c|}{$\begin{array}{c}\text { Number of Causalities } \\
\text { and Injury Severity }\end{array}$} \\
\hline & & & Major & Minor \\
\hline Miyakonojo City & $10-30$ & $\begin{array}{l}\text { Related to tephra removal, including falls } \\
\text { from ladders and roofs }\end{array}$ & 15 & 18 \\
\hline Takaharu Town & $2-20$ & $\begin{array}{l}\text { Related to tephra removal, including slips } \\
\text { from steps }\end{array}$ & 2 & 1 \\
\hline Kirishima City & $\mathrm{n} / \mathrm{a}$ & Cut by window glass broken by shockwaves & & 1 \\
\hline Total & & & 17 & 20 \\
\hline
\end{tabular}

onto a truck and then emptied at the tephra dump site. This was physically demanding and time consuming. Cleanup for small businesses was a large undertaking typically involving most staff members and often requiring overtime.
Large companies such as shopping centres employed contractors immediately following the main eruptive phase to undertake cleanup activities.

In both Miyakonojo and Takaharu provisions were made 


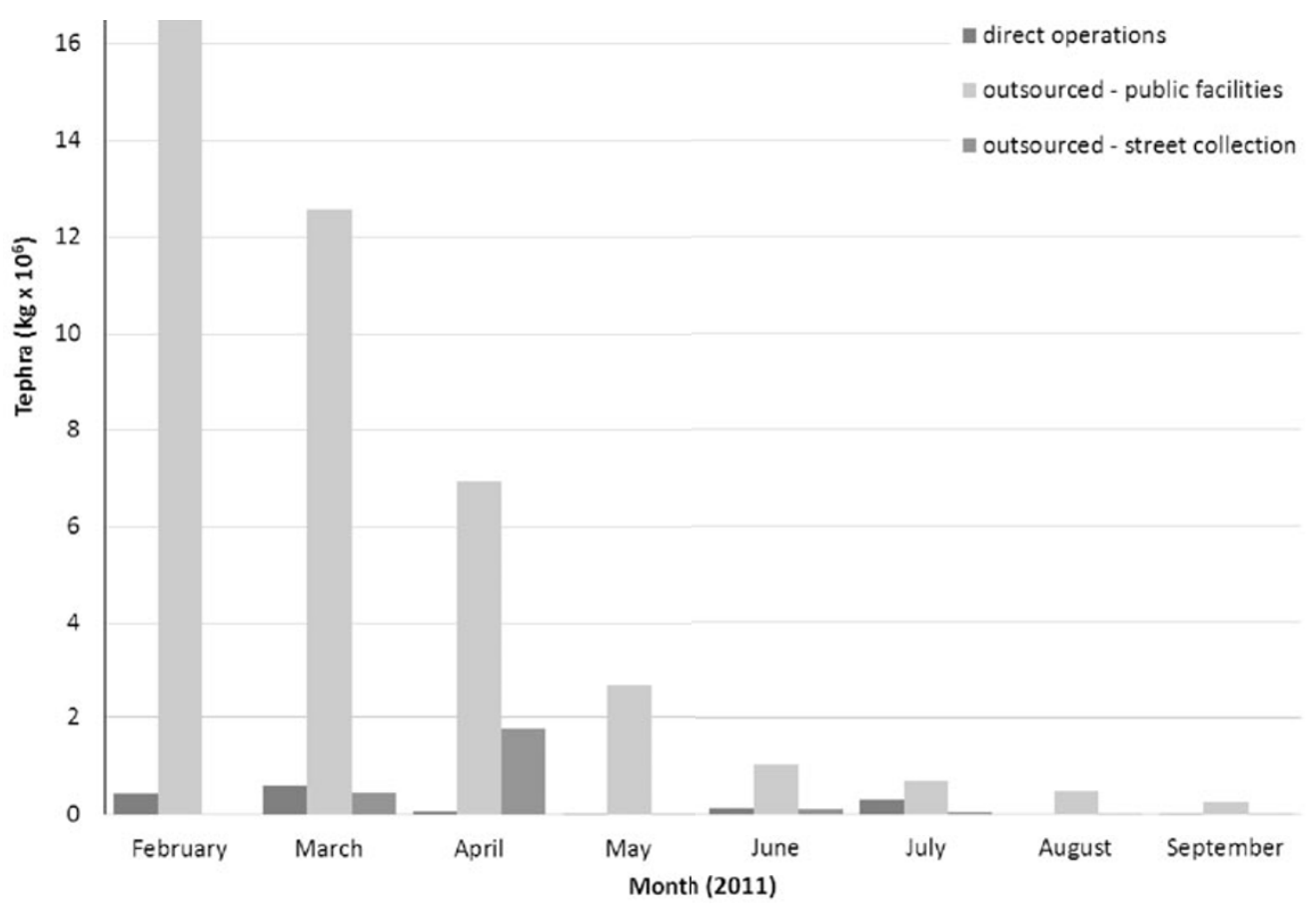

Fig. 3. Tephra fall amounts administered by Miyakonojo City Government. These values relate only to residential and public areas. Direct operations are those carried out by Miyakonojo City Government staff and include public facilities and public housing. Outsourced operations are broken down into those dealing with public facilities (including rubbish stations where residents brought tephra) and street collection of tephra collected by residents from properties. Data provided by Miyakonojo City Government.

for those needing assistance, particularly elderly residents. Takaharu town organised groups of trained volunteers such as fire-fighters to work on roofs with teams of 5 people cleaning 4 houses per day. It took from 7 February through to mid-March for all identified properties to be attended to. Volunteers were sourced both from within and beyond Miyazaki Prefecture.

Regions in Japan that had previously experienced volcanic crises readily provided help and resources. In particular, 31,000 tephra collection bags were provided by Shimabara, previously affected by Unzen volcano (19911995), and 500,000 additional bags were sourced from other prefectures (Takaharu Town office, personal communication November 2011). These bags were made of strong plastic and held about $10 \mathrm{~kg}$ of tephra. Support and advice on road-surface cleaning was provided by Kagoshima City and vehicles were sent by the Ministry of Land, Infrastructure, Transport and Tourism (MLITT) from a number of locations in Japan. However, local governments affected by tephra fall were responsible for expenses such as wages of operators and fuel. Earth moving machinery and dump trucks were leased or supplied by local construction companies.

During the eruption and whilst conducting cleanup activities, it was observed that almost every person outside wore a facemask to avoid breathing in ash. This is in large part due to the strong culture in Japan of wearing facemasks to protect against flu, hay fever allergens and other respiratory health concerns and masks being readily available. Workers involved in commercial cleanup activities were well protected, with full face masks, helmets and full body overalls in line with international best-practice (see: www.ivhhn.org). However, the task for professional and non-professional cleanup crews was physically demanding and workers complained of injuries including back problems.

In addition to the use of tephra as landfill, several secondary uses were being trialled: a company in Miyakonojo began production of reinforced bricks; a potter from Hyuga city (north coast of Miyazaki Prefecture) had sourced quantities of tephra; and, one community activity was a demonstration of the use of tephra in cooking meat to retain moisture. Large sandbags $\left(\sim 5 \mathrm{~m}^{3}\right)$ were constructed and installed effectively by MLITT and local governments as an emergency measure against lahar inundation. As of 12 April 2011, 1,850 bags were filled with 47 installed at Haraigawa and 326 at Kamamutagawa (Takaharu Town, 6$8 \mathrm{~km}$ from the vent).

6.1.3 Cleanup data analysis It is useful to consider the amount of tephra dealt with by various cleanup operations. Data for this purpose is available only for Miyakonojo City (Fig. 3). In total, an estimated $1.52 \times 10^{6}$ $\mathrm{kg}$ of tephra was collected and removed by direct operations involving Miyakonojo City Government staff. This included removal from government and public facilities including public housing. The majority of cleanup activities were outsourced, with $42.14 \times 10^{6} \mathrm{~kg}$ of tephra removed from public facilities and local waste stations, and $2.37 \times 10^{6} \mathrm{~kg}$ picked up from the street after collection by residents from private properties. We assume these values are only associated with cleanup of urban areas.

By considering the area and average accumulation of tephra in Fig. 2(a), we can estimate that approximately $160 \times 10^{6} \mathrm{~kg}$ of tephra was deposited on urban land within 
Table 8. Numbers of vehicles sent to Miyakonojo City, Nichinan City, Takaharu Town, Kushima City, Kobayashi City, Mimata Town and Kirishima City from prefectures outside the affected area (Ministry of Land, Infrastructure, Transport and Tourism, 2011).

\begin{tabular}{lccc}
\hline & Vehicles sent & Total vehicle-days & Average vehicle-days \\
\hline Sprinkler truck & 31 & 675 & 21.8 \\
Road sweeper & 40 & 1,414 & 35.4 \\
Management car & 4 & 212 & 53.0 \\
\hline Total & $\mathbf{7 5}$ & $\mathbf{2 , 3 0 1}$ & $\mathbf{3 0 . 7}$ \\
\hline
\end{tabular}

Table 9. Costs of tephra cleanup related projects in Takaharu Town (Takaharu Town, 2011b).

\begin{tabular}{cr}
\hline \multicolumn{1}{c}{ Project } & Cost (JPY) \\
\hline 2010 Financial year (up to end March 2011) & \\
Collection and transfer of tephra & $2,688,000$ \\
Road cleanup operations & $15,473,000$ \\
Manufacture of tephra-collection bags & $2,399,000$ \\
Tephra removal from agricultural facilities & $12,528,000$ \\
2011 Financial year (from April 2011) & \\
Tephra collection & $2,184,000$ \\
\hline
\end{tabular}

Miyakonojo. This allows us to approximate that $1 \%$ of tephra was removed by direct municipal operations, $26 \%$ by outsourced cleanup of public facilities and rubbish stations and $1.5 \%$ by street collection. If these values are consistent across the entire affected area then we may assume that $28.5 \%$ of the total fallen tephra in urban areas (estimated as $1470 \times 10^{6} \mathrm{~kg}$ for the first three days of the eruption) was dealt with by government managed cleanup operations. This is equal to approximately $420 \times 10^{6} \mathrm{~kg}$ or 420,000 tons of tephra. The tephra not accounted for here would have been dealt with by businesses or other private organisations, removed by road cleanup operations, been washed or blown elsewhere or remains in place. Cleanup of public facilities occurred quickly with most tephra removed in February and then decreasing amounts in following months. However, street collection was slower, not beginning until March with the largest amounts collected during April (Fig. 3).

Takaharu Town Hall advised that it took one week to clean major roads but that cleaning of minor agricultural roads was not completed until late March. Takaharu Town Hall advised that they were responsible for cleaning 307.4 $\mathrm{km}$ of roads. Small sweeper trucks covered $39.6 \mathrm{~km}$ (1.6 $\mathrm{km} /$ day) and large sweepers $267.8 \mathrm{~km}(3.9 \mathrm{~km} /$ day $)$. This means that in total 44 sweeper days were needed; although, it is unclear how many sweeper trucks were available.

A number of vehicles were dispatched to the affected area from outside prefectures (Table 8). In addition to vehicles, 127 liaison officers were sent from other regions to the Miyazaki Prefecture Office between 26 January and 31 March, although it is unclear how long each person was based in the area. In this initiative, road surface cleanup was conducted between 27 January and 23 February with an estimated 2,324 $\mathrm{m}^{3}$ of tephra collected (Ministry of Land, Infrastructure, Transport and Tourism, 2011).

By considering the total length of roads affected, we may approximate the volume of tephra removed from roads. It is difficult to estimate a minimum volume of tephra that required roads to be cleaned, as vehicles were often responsible for removing tephra to the side of the road prior to any specialised cleaning. However, personal correspondence with Tarumizu City Hall (2007), who received frequent tephra falls from Sakurajima volcano, suggested that a threshold of $0.5 \mathrm{~kg} / \mathrm{m}^{2}$ was sufficient for road markings to be obscured. We therefore assume this threshold here and estimate the total road accumulation to be approximately $95 \times 10^{6} \mathrm{~kg}$. Note that local roads in more rural areas are not included in this value.

In terms of the costs of cleanup activities, we again only have very limited data from which to draw any conclusions. Table 9 lists the costs of projects related to cleanup for Takaharu Town. These values relate to the costs incurred to the town, i.e. they exclude costs to businesses. From exposure calculations, we remind the reader that $36.8 \mathrm{~km}^{2}$ of land area was tephra affected in Takaharu (all $<0.5 \mathrm{~kg} / \mathrm{m}^{2}$ ), which equates to $42.6 \%$ of the total land area. Of this, 10 $\mathrm{km}^{2}$ was agricultural land and only $0.1 \mathrm{~km}^{2}$ urban. We apply a road length equal to $307.4 \mathrm{~km}$.

Tephra collection in Takaharu to the end March 2011, including the manufacture of bags but excluding road and agricultural facility operations, cost 5,087,000 JPY ( 66,000 USD) (Table 9), and the total amount of tephra collected by individuals as at 25 March was estimated to be $221,720 \mathrm{~kg}$ (Takaharu Town, 2011c). We can therefore estimate that cleanup for urban areas cost approximately 23 JPY ( 0.30 USD) per kg. Road cleanup operations can be estimated to have cost approximately 50,300 JPY (650 USD) per $\mathrm{km}$ or $17 \mathrm{JPY}(0.22 \mathrm{USD})$ per kg, assuming an average road width of $6 \mathrm{~m}$ and average tephra accumulation of $0.5 \mathrm{~kg} / \mathrm{m}^{2}$.

\subsection{Agriculture}

Within several days of the onset of the eruption and during our first visit to the area, tephra had been deposited across an estimated $564 \mathrm{~km}^{2}$ of agricultural land, with 30 $\mathrm{km}^{2}$ exposed to $>10 \mathrm{~kg} / \mathrm{m}^{2}$ (Fig. 2(a) and Table 3). At this time the greatest concerns were of effects to crops that were still growing or ready for harvest as well as physical and chemical fertility changes to soils.

Agricultural extension agencies, Japan Agriculture (JA, a farmers' cooperative), the Agriculture Improvement and 
Table 10. Summary of agricultural damage from the 2011 Shinmoedake eruption (as of 31 March 2011) (Agriculture Improvement and Promotion Centre, 2011). Original data provided by Department of Agricultural Policy and Fisheries of Miyazaki Prefecture.

\begin{tabular}{lcc}
\hline & Damaged area & $\begin{array}{c}\text { Damage Value } \\
\text { (thousand JPY) }\end{array}$ \\
\hline Agricultural crops and facilities (total) & 12,554 ha & 608,000 \\
$\quad$ Outdoor vegetable & & 279,680 \\
Greenhouse horticulture & & 115,520 \\
Forage crops & & 97,280 \\
Facilities & & \\
Agricultural lands (soil) & 665 farms & 595,000 \\
Fisheries & 1 farm & 1,000 \\
\hline Total & \multicolumn{3}{c}{$\mathbf{1 , 2 0 4 , 0 0 0}$} \\
\hline
\end{tabular}

Promotion Centre (AIPC) and the Farming Support Division of Miyazaki Prefecture, undertook extensive crop impact assessments and analysed the composition of tephra and its effect on soils. These groups also provided bestpractice mitigation and remediation advice and managed damage claims from farmers. Utilising excellent preeruption records, the magnitude of the impacts were able to be estimated and needs assessed to facilitate central government aid. The total cost to the agricultural sector was estimated at 1,204 million JPY ( $\sim 15.5$ million USD), split between reduced or lost crop production and damage to agricultural land requiring rehabilitation (Table 10) (Department of Agricultural Policy and Fisheries of Miyazaki Prefecture, 2011).

Approximately 1 billion JPY (13 million USD) was provided to Miyazaki prefecture by central government for agricultural cleanup operations. As only one season of outdoor crops had been lost and the majority of fields were fallow, or hadn't yet been planted, no financial support was given for crop losses. However, as greenhouse crops and tea crops were still growing, cleanup support was provided for this sub-sector. Qualifying farmers were required to pay one third of the cost with the remainder funded from the subsidy up to a cap of 1 million JPY (13,000 USD). Required products, such as air-blowers and water-sprayers, were purchased and distributed by JA and AIPC but this often took several days to weeks due to the high demand.

\subsection{Outdoor crops}

6.3.1 Impacts The time of year that the eruption occurred was crucial in determining what impacts were sustained by the agricultural sector (also see, Wilson and Cole, 2007). Many crops in the area had been harvested in November/December and the fields were fallow. However, crops such as potatoes and burdock root had recently been planted and spinach crops were ready for harvest. Our observations and reports from interviewees suggested that, generally, any exposed crop suffered tephra adherence (Fig. 4), often leading to deficiency in photosynthetically active radiation and acid leaching damage. In particular, fine grained, sharp tephra particles strongly adhered to the leaves of most crops, including waxy leaved spinach and tea, making cleaning difficult. Effects were wide ranging, depending on the stage of crop development. In some instances, abrasion occurred during windy conditions, cleaning and harvest. High terminal velocities of relatively coarse-grained tephra (sand-sized) caused bruis- ing and shredding in some locations, particularly of young seedlings.

Accumulations of more than $10 \mathrm{~kg} / \mathrm{m}^{2}$ led to smothering and limb breakage in leafy ground crops (e.g. spinach, potatoes, etc.). In general the quality and quantity of harvest were reduced and was loosely correlated with tephra accumulation. In extreme cases the harvest failed and the crop was written off. Unmarketable crops were ploughed into fields as mulch. Table 11 summarises damage observations and mitigation actions. The most severe impacts to outdoor crops were 665 farms classified as being 'buried' by tephra (typically where falls exceeded $10 \mathrm{~kg} / \mathrm{m}^{2}$ ), which required the rehabilitation of soils. This could be broken down to 308 rice paddies (224 ha) and 357 cultivated 'fields' (620 ha) (Department of Agricultural Policy and Fisheries of Miyazaki Prefecture, 2011).

Initial analysis of the tephra by AIPC established high levels of available sulphur, which was feared would produce $\mathrm{H}_{2} \mathrm{~S}$ and reduce soil $\mathrm{pH}$ and chemical soil fertility, particularly for rice paddies sensitive to high levels of $S$ and low $\mathrm{pH}$. Such changes to soil chemistry by andesitic tephra fall were observed following the 1995 Ruapehu eruptions in New Zealand (Cronin et al., 1998). However, agricultural officials and farmers reported that the Shinmoedake tephra appeared to have limited, if any, affects on soil $\mathrm{pH}$ in the 3-6 months following the initial tephra falls, particularly following rehabilitation (see below). The tephra was not reported to have affected crops planted following the eruption.

Tephra accumulation greater than $10 \mathrm{~kg} / \mathrm{m}^{2}$ reportedly reduced water infiltration due to a semi-impermeable crust layer forming. Whilst this would also have acted much like a mulch to retain moisture, farmers reported that when coupled with a following dry period, this led to moisture stress on crops. This is consistent with experiences following thick tephra deposition after the 1991 Hudson eruption in Chile and Argentina (Wilson et al., 2011).

6.3.2 Management In general, losses to individual farms were considered to be relatively low, due to farmers taking appropriate mitigation measures, coupled with a cleanup and rehabilitation subsidy from central government. Mitigation efforts for agriculture and horticulture focused on two broad themes: 1) removing tephra from established plants and 2) removing (striping) or ploughing tephra into soils.

In general, farmers reported that the faster they undertook 

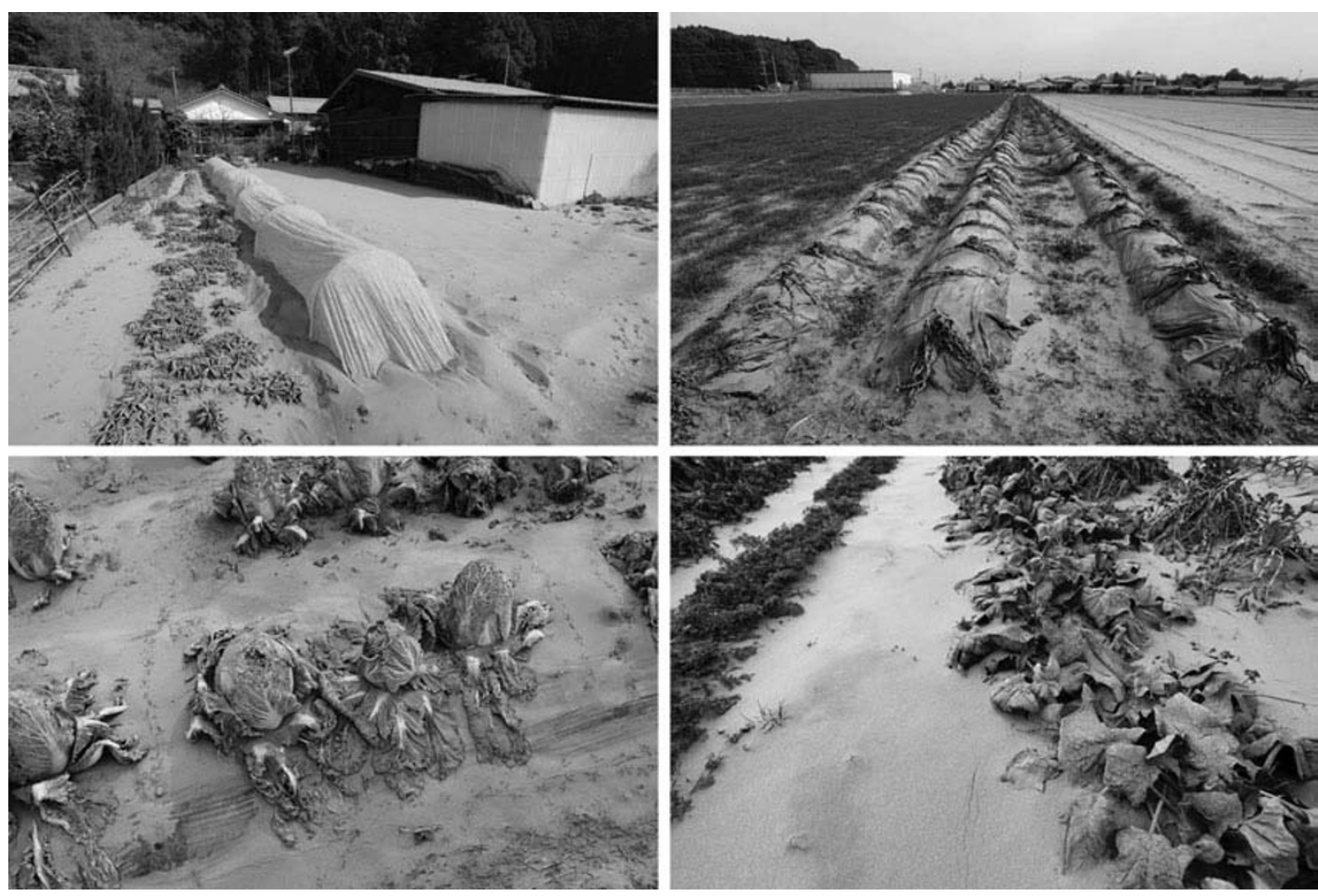

Fig. 4. Spinach and cabbage crops in Yamada damaged by tephra (2 February 2011). Photo in top left shows a typical home garden in the area while the other three show rows of vegetables in small farms.

mitigation actions the better the outcome. For example, JA stated that potato farmers experienced $10 \%$ losses in the June harvest yield where cleaning and tephra removal occurred within days of tephra fall, compared to 30-50\% losses where no mitigation measures were taken.

Some farmers used air blowers and water sprayers to remove tephra from plants; with particular attention paid to spinach and tea crops (Table 11). This was time consuming and often not considered cost effective. However, established tea farms successfully used a modified selfpropelled sprayer (four purchased with government aid) to wash plants. This method had been developed for use in Kagoshima to mitigate frequent tephra falls from Sakurajima volcano. The mitigation efforts were credited with a minimal reduction in production during the following season.

It was recommended by AIPC that tephra deposits $<3$ $\mathrm{cm}\left(\sim 33 \mathrm{~kg} / \mathrm{m}^{2}\right)$ be mixed into the soil through standard cultivation practices and that when $>3 \mathrm{~cm}$ should be removed where possible to avoid a reduction in soil fertility. The following procedure was recommended by AIPC for ash affected farms:

1) Tephra be removed from fields and channels (particularly when $3 \mathrm{~cm}$ or greater).

2) Deep ploughing or over-turning $(15 \mathrm{~cm}$ for rice paddies, $20 \mathrm{~cm}$ or greater for fields) to mix and bury the tephra and in order to avoid creating a sandy texture. It was suggested that this could then be followed by a rotary hoe to aerate the soil; however, this step was generally avoided due to fears of bringing tephra back to the surface. Tilling was also avoided as it did not adequately bury the tephra.
3) $\mathrm{Mg}-\mathrm{CaCO}_{3}$-based fertiliser added to mitigate acidity ( 0.5 to $1.0 \mathrm{t} / \mathrm{ha})$. For rice paddies this was to be followed by application of Fe fertiliser to suppress $\mathrm{H}_{2} \mathrm{~S}$.

4) Organic material (manure) added to offset reductions in Cation Exchange Capacity (CEC) and waterholding capacity.

5) On-going monitoring of soil fertility characteristics.

In many cases, rice paddies could not have their soil base broken by cultivation, so removal of tephra by scrapping was the only treatment option available. This was inefficient due to the rough surface caused by stumps of rice; however, no yield reductions were reported.

The resource intensive procedure of tephra removal exceeded the capacity of many farmers. Removing tephra from paddocks required larger machines than most farmers owned and local contractors did not have sufficient resources to meet demand. Despite government financial assistance, only a small proportion of farmers were able to clear their land of tephra and many ended up simply mixing all the fallen tephra into the soil, even with up to $10 \mathrm{~kg} / \mathrm{m}^{2}$ accumulation.

The management of collected tephra was viewed by farmers as one of the more significant challenges during the eruption. Where needed, farmers used dump trucks, bulldozers and loaders to strip tephra from fields. When time allowed, tephra was added to that collected from building roofs, and eventually moved to a collection point (near the road) where the council would collect it with heavy machinery. Others who didn't have the time or resources to move it simply stockpiled the tephra in unused areas on farms or on a part of a paddock that was sacrificed.

Cultivation machinery was reportedly mostly unaffected 


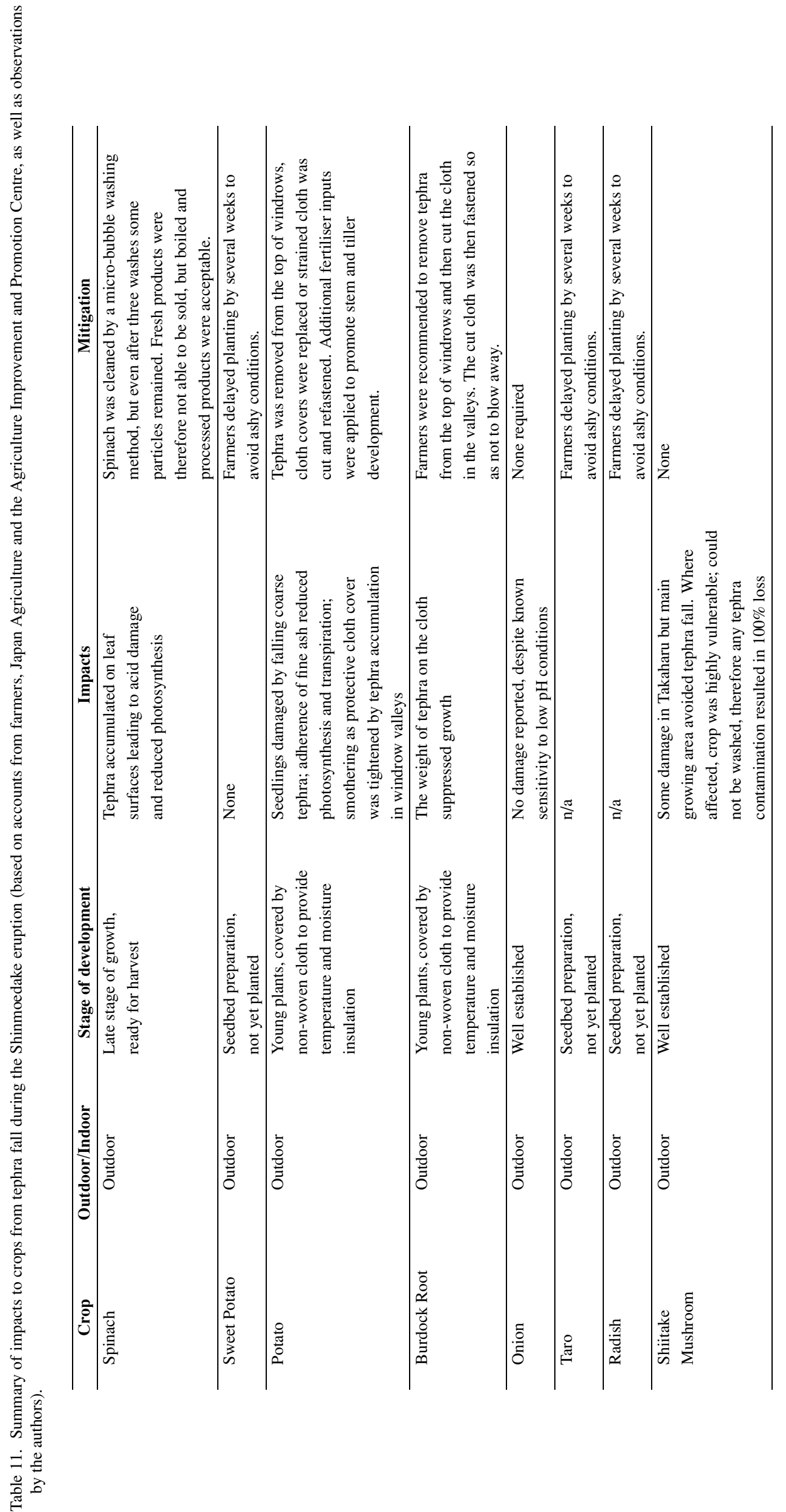




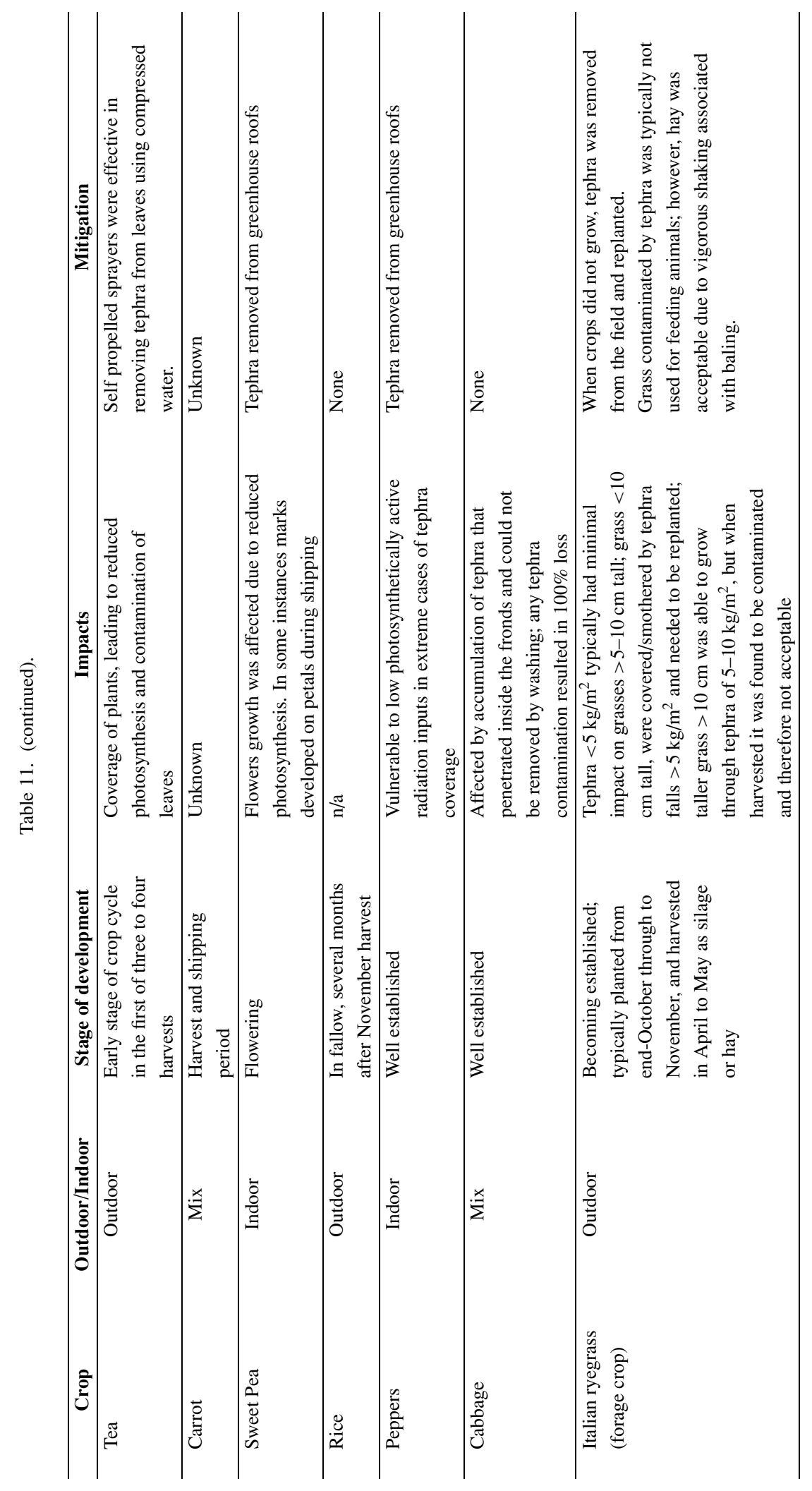



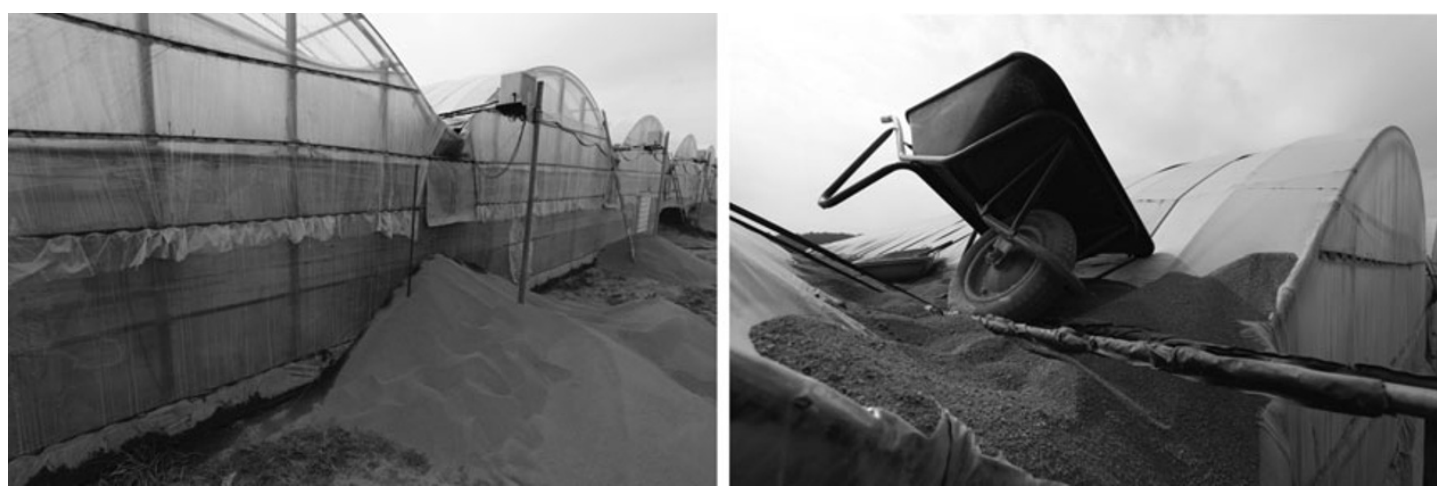

Fig. 5. Greenhouse affected by tephra in Yamada (2 February 2011). Photo on the left shows piles of tephra already removed from valleys in the greenhouse roof and, on the right, tephra still remaining on the roof.

by operating in tephra deposits, although operators often increased the frequency of maintenance.

\subsection{Greenhouse horticulture}

6.4.1 Impacts Greenhouse agriculture is common in the study area. Farms with greenhouses are typically smaller in area than open-air equivalents, with some wholly reliant on greenhouses for production, whilst others combine open-air (sub-aerial) production. Greenhouses are constructed on a light metal frame with a clear vinyl cover, and have mechanical cranks to open panels for ventilation. Roofs are domed with ' $v$ ' shaped valleys between spans (Fig. 5). Experiences during the eruption suggested the greenhouses provided effective protection from direct tephra fall; however, tephra accumulated on the shallow pitched roofs and, in particular, between roof spans reduced solar radiation levels inside the greenhouse, resulting in reduced crop growth rates. Only in rare instances did the vinyl coverings break or tear due to tephra loading; and where tears did develop, they tended to be due to abrasion where the vinyl vents slid along the greenhouse's metal frame. Within $10 \mathrm{~km}$ of the volcano, clasts $(>10 \mathrm{~mm})$ punched holes in the vinyl of several greenhouses, with 10 requiring remediation (Department of Agricultural Policy and Fisheries of Miyazaki Prefecture, 2011).

Tephra loads on the vents inhibited opening and therefore aeration. The combination of reduced light levels and increased humidity increased the prevalence of disease. Interviewees noted that it was fortunate the eruption occurred in winter, as failure to ventilate greenhouses during the humid and hot summers conditions would have caused more significant problems. It was found that the low level of sunlight entering the greenhouse also reduced the performance of bees used to pollinate strawberries and other crops.

Most significantly, farmer's efforts were diverted towards cleanup. Farms were often staffed by only two, often elderly, people and crop quality was reduced as removal of tephra from greenhouses was prioritised over tasks such as cultivation and tending crops.

6.4.2 Management The major action required was the removal and cleaning of tephra from greenhouses with most attention needed to remove tephra accumulated in the valleys between spans (e.g. images in Fig. 5). Air blowers were used when accumulation in the valleys was less than approximately $5 \mathrm{~kg} / \mathrm{m}^{2}$ and this was often followed by washing with water. Where tephra exceeded $5 \mathrm{~kg} / \mathrm{m}^{2}$, shovels and wheelbarrows were employed. This was time consuming, with typical clearance rates for two people of approximately 1 hour per metre. Greenhouse roof construction contributed greatly to the task of cleanup and may also have been vulnerable to failure in the case of thicker falls. In tephra fall prone areas such as Miyazaki, it may be necessary to consider single spans in roof design.

It was prohibitively expensive for farmers to hire professional contractors, whose specialists skills were also required for assisting high priority tasks such as cleaning and maintenance of critical infrastructure. Farmers approached JA and AIPC for assistance, but these organisations did not have the human resources to assist on the scale required. Local college students volunteered to assist; however, management, support, and health and safety considerations meant their offer was declined.

\subsection{Forage crops}

6.5.1 Impacts The most common forage crops in the affected area were Italian ryegrass and corn. The eruption occurred at a vulnerable time for livestock farmers with grasses recently germinating and becoming established. Where grasses were taller than the tephra deposit thickness, they typically continued to grow through tephra successfully. However, where tephra accumulation was sufficiently large, and grass short, crops were smothered (Table 11). Tephra contamination of grass was still a significant issue during harvest (in April, 3 months after the main tephra fall), prompting a recommendation from JA that fresh grass not be used for feeding animals. Dried grass (hay) was recommended as shaking during cutting and baling removed most of the tephra.

6.5.2 Management Where forage crops were lost, fields appeared to be remediated quickly and successfully. As one example, Miyazaki Prefecture Public Livestock Corporation (MPPLC), who manages 150 ha of farms several kilometres from the volcano, received $7-10 \mathrm{~kg} / \mathrm{m}^{2}$ of tephra as well as occasional clasts up to $7 \mathrm{~cm}$ in diameter. Most of the farm's forage crops were buried, with soils undergoing deep ploughed to $60-70 \mathrm{~cm}$ as a first step in remediation. A rotary hoe was then used for seedbed preparation. Nitrogen-Phosphorus-Potassium (N-P-K) fertiliser was added with the seed, but suggested $\mathrm{Mg}-\mathrm{CaCO}_{3}$ could not be sourced quickly and planting proceeded without it. 


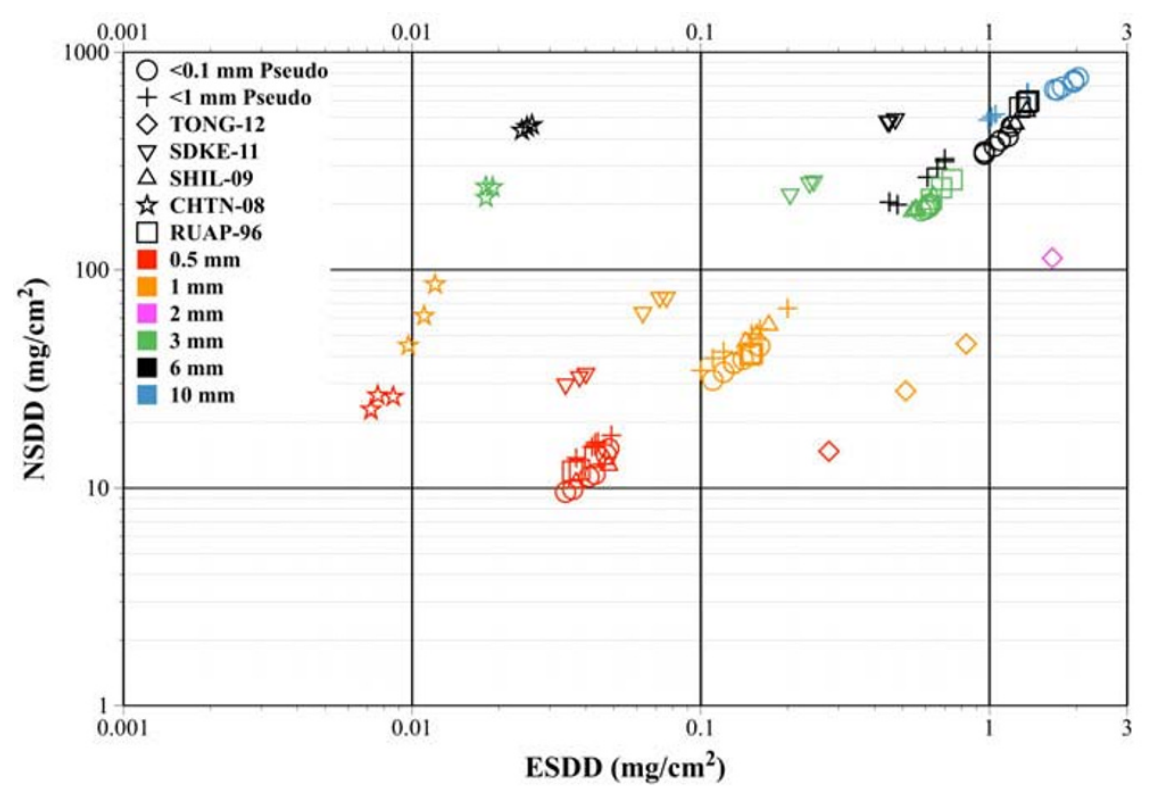

Fig. 6. Shinmoedake tephra (SDKE-11) non-soluble deposit density plotted against equivalent soluble deposit density. Other tephras plotted for comparison include: August 2012 eruption of Tongariro volcano, New Zealand (TONG-12); January 2009 eruption of Soufriere Hills, Montserrat (SHIL-09); June 2008 eruption of Chaiten volcano, Chile (CHTN-08); June 1996 eruption of Ruapehu volcano, New Zealand (RUAP-96); and synthetic "pseudo-tephra" (see Broom, 2010). Figure adapted from Wardman et al. (2013).

A one-off crop of oats and Sudan grass was planted to grow quickly and have high nutrition value; this was harvested in July. Any contamination to the oats/Sudan grass from ongoing light tephra falls or remobilisation of existing tephra deposits did not cause any significant additional damage to forage or affect livestock health.

\subsection{Livestock}

6.6.1 Impacts Despite a large number of livestock farms exposed to tephra fall, few problems were reported. Direct exposure to tephra was minimal as livestock are mostly kept indoors and tephra did not contaminate the covered feeding stalls or water troughs. Impacts were largely limited to forage crops (see section above) and instances where large clasts penetrated plastic corrugated roofs spooking livestock. A total of 207 lightly constructed cowsheds and forage warehouses were either damaged or collapsed under the weight of tephra (Department of Agricultural Policy and Fisheries of Miyazaki Prefecture, 2011).

6.6.2 Management Two cattle farms were evacuated beyond the tephra-affected area due to clast impacts to barn roofs. This evacuation was coordinated by JA who provided non-financial support including human resources and trucks. Many of these livestock still remained on host farms nine months later to avoid further stress to animals.

Where necessary, due to loss of forage crops, farmers fed livestock from supplementary feed reserves (e.g. round silage bales and silage bunkers), with most farmers having up to two months reserve supply. Once these supplies were exhausted, clean supplementary feed was purchased, but at a high cost as it was out of season.

\subsection{Electric power systems}

6.7.1 Impacts Kyushu Electric Power Company (KEPC) manages the generation, transmission and distribution of electricity throughout Kyushu. In the tephra-affected area, the network consists of a series of transmission lines (above ground towers with suspended 110, 220 and 500 $\mathrm{kV}$ circuits) that connect hydroelectric, thermal and nuclear generation stations with large industrial users and a dispersed distribution network. Voltages are stepped down to $66 \mathrm{kV}$ for distribution networks, stepped down again to 6 $\mathrm{kV}$ for zone distribution, and to $200 \mathrm{~V}$ and $100 \mathrm{~V}$ for urban and rural domestic customers. Insulators on KEPC's transmission and distribution networks are typically ceramic, which is common globally. However, to protect against industrial pollution contamination, extra long insulator strings are used on 110, 200 and $500 \mathrm{kV}$ circuits; the $6 \mathrm{kV}$ distribution systems are protected by polyethylene jackets and 200 $\mathrm{V}$ and $100 \mathrm{~V}$ insulators have vinyl jackets.

During the Shinmoedake eruption over $136 \mathrm{~km}$ of HighVoltage (HV) transmission circuits $(>67 \mathrm{kV})$ and $123 \mathrm{~km}$ of $60 \mathrm{kV}$ circuit were exposed to tephra fall (Table 5). Significantly, there was a period of light misty rain from 7 to 10 February, which moistened deposits remaining on insulators, increasing the conductivity of deposits and thus the likelihood of insulator flashover (Wardman et al., 2012b).

There were no direct disruptions to the KEPC HV transmission network (generation sites, lines or transformer facilities) as the result of tephra fall, although over $24 \mathrm{~km}$ of circuits and transforming stations were exposed to more than $3 \mathrm{~kg} / \mathrm{m}^{2}$ of tephra, and $10 \mathrm{~km}$ to over $10 \mathrm{~kg} / \mathrm{m}^{2}$ (Fig. 2(d) and Table 5).

There were no reports of leakage current or flashovers on the $66 \mathrm{kV}$ or $6 \mathrm{kV}$ networks. However, some leakage and flashovers were reported on the $200 \mathrm{~V}$ and $100 \mathrm{~V}$ distribution system. From the beginning of the eruption through to 24 May, KEPC received 54 reports from customers of electricity leakage (strong crackling or arcing sound) and 29 reports of flashover causing disruption of supply from the local transformer to the customer. The vast majority of these incidents occurred at connection points or where the insu- 
lator's jacket cover had been scratched or abraded. Most of the reports occurred between 7 and 10 February during the period of light rain. Most reported problems ceased following heavy rain on 10 February suggesting that most tephra was washed off equipment during this time.

Pristine tephra was collected in various locations in Miyakonojo City between 28 January and 3 February and equivalent salt deposit density (ESDD) measurements, taken as a measure of contamination potential, were made using the International Electrotechnical Commission (IEC) 60815 site pollution severity guidelines (IEC, 2008). Figure 6 shows non-soluble deposit density (NSDD) vs. ESDD with Shinmoedake tephra compared against other tephra fall deposits (from Wardman et al., 2013). Results indicate that more than $3 \mathrm{~mm}\left(3.3 \mathrm{~kg} / \mathrm{m}^{2}\right.$, assuming a deposit density of $1100 \mathrm{~kg} / \mathrm{m}^{2}$ (AIST, 2011)) of the Shinmoedake tephra can be considered a very heavy contaminant for electrical insulators, according to IEEE (1979) (the global standard for contaminant severity in electrical engineering). The Shinmoedake tephra plots within the middle range of ESDD/NSDD values when compared to tephras from other eruptions analysed by Wardman et al. (2013).

The ESDD/NSDD analysis suggests that, when wet, the tephra was highly conductive. However, the lack of noted disruptions suggests that the tephra was never wetted sufficiently to increase conductivity or cause adherence to insulator components. The first rain was not until 7-10 days after the main falls, allowing time for natural cleaning by wind. KEPC cleaning of tephra-contaminated insulators had also occurred in many substations before this time. On distribution networks tephra exposure did not create a widespread problem, possibly highlighting the value of anti-pollution protection on insulators.

Several Hydroelectric Power (HEP) Generation Facilities and their catchments were exposed to tephra falls throughout the eruption. The first problems to manifest were that rain gauges filled with tephra at climate stations throughout the river catchments. These required regular cleaning to keep the stations functional in monitoring catchment rainfall intensities. Two HEP stations, Nojiri (approximately 16 $\mathrm{km}$ northeast of the vent) and Mizonokuchi (approximately $15 \mathrm{~km}$ southeast of the vent), experienced thick tephra falls in their catchments, which required a lahar monitoring program to be initiated. Following the heavy rainfall on 10 February it was decided that these two stations be shut down and water was bypassed between 10 and 11 February as a precautionary measure. The small dam size of the two HEP stations allowed tephra laden water to clear quickly and, therefore, shutdown- and restart-operations to occur without incident.

6.7.2 Management On 27 January, following the initial tephra fall, KEPC staff began to patrol generation, transmission and distribution networks. Operational tempo was increased, including more frequent internal communication and cleaning of tephra contaminated assets; however, activation of specialist emergency management groups within the company was not required. Traffic disruptions during this period increased the time it took field crews to complete tasks.

On 1 February, KEPC began to de-energise (shut down) some facilities for precautionary cleaning of transformers, following accumulation of several centimetres of tephra on transformer insulators. This was not triggered by excessive tephra accumulation; rather it was due to a warning that the exclusion zone was to be extended making it unclear when access to some sites would be restored. Cleaning took place while rerouting through other circuits and without disrupting the supply of electricity to customers.

On transmission networks, cleaning was mostly restricted to substation facilities. A special hot-stick (insulated pole) was developed with a compressed air line attached for live (energised) cleaning. A hot-stick with a high-pressure water line was also developed, but due to the uncertain conductivity of tephra at the time, this was only used when the system was de-energised. When facilities were de-energised, tephra could also be wiped off surfaces with a cloth where practical. There was some benefit from rain cleaning accumulated tephra, but it was unclear to what extent.

In some parts of the affected area there is a wellestablished program of live (energised) insulator cleaning to minimise insulator contamination from sea salt, which KEPC staff believed reduced the likelihood of tephra induced flashover. In addition, some lines also have an autowashing system to remove sea salts, whilst others use a higher rated (longer) insulator to provide greater insulation.

Cleaning was not undertaken on distribution lines due to the extensive networks and high remaining functionality. A reactive approach was adopted where any report from the public of leakage current or flashover was responded to and a program of limited energised water cleaning of insulators was initiated.

\subsection{Rail network}

6.8.1 Impacts JR Kyushu Railway Company is responsible for much of the rail network within Kyushu, with an estimated $186 \mathrm{~km}$ of rail and 48 stations affected to some degree by tephra during the Shinmoedake eruption (Fig. 2(c) and Table 6). Train cancellations and delays occurred on the Nippo Mainline, Kitto Line and Nichinan Line (Fig. 2(c)) between 26 and 28 January with cancellations on the Kitto Line occurring through to 5 February (Table 12). Two key problems affected train services during the eruption: the mechanical failure of track switches due to a build up of tephra and loss of electrical contact between track and train wheels disrupting communications. Also of concern to the company was the additional risk posed by potential lahars. It was determined that if an evacuation call was made then all services would be stopped in the hazardous area.

The rail system operates where electrical signals are communicated to trains through the tracks. Operators can nearcontinuously follow where each carriage is for safe and efficient operation of the network. If the signal is lost then an emergency system is activated and the train is brought to a stop. During the Shinmoedake eruption, tephra acted as a barrier between the wheels and the tracks inhibiting the signal. It was therefore essential for tracks to be cleaned so that operations could continue. This was the most significant service disruption experienced during the eruption. There did not seem to be a critical threshold where con- 
Table 12. Summary of rail cancellations and delays during the Shinmoedake eruption. Data provided by JR Kyushu (November 2011).

\begin{tabular}{|c|c|c|c|c|c|c|c|}
\hline \multirow[t]{2}{*}{ Date } & \multicolumn{2}{|c|}{ Operations suspended } & \multirow[b]{2}{*}{ Reason } & \multirow[b]{2}{*}{ Time } & \multirow{2}{*}{$\begin{array}{l}\text { Cancelled services } \\
\text { (Including partial) }\end{array}$} & \multicolumn{2}{|c|}{ Delayed services } \\
\hline & Line & Section & & & & Cases & Minutes \\
\hline \multirow[t]{3}{*}{26 January } & Kitto & Yoshimatsu-Miyakonojo & switch failure & 17:53-last & 6 & & \\
\hline & Nippo & Tano-Kokubu & switch failure & $17: 15$-last & 48 & 5 & $27-1336$ \\
\hline & Nichinan & Miyazaki-Shibushi & switch failure & 18:05-last & 10 & & \\
\hline \multirow[t]{3}{*}{27 January } & Kitto & Yoshimatsu-Miyakonojo & switch failure & All day & 18 & & \\
\hline & Nippo & Tano-Kokubu & $\begin{array}{l}\text { lost connection } \\
\text { switch failure } \\
\text { lost connection }\end{array}$ & All day & 73 & 15 & $5-796$ \\
\hline & Nichinan & Miyazaki-Shibushi & $\begin{array}{l}\text { switch failure } \\
\text { lost connection }\end{array}$ & All day & 30 & 2 & $29-35$ \\
\hline \multirow[t]{3}{*}{28 January } & Kitto & Yoshimatsu-Miyakonojo & lost connection & First-21:30 & 19 & & \\
\hline & Nippo & Tano-Kokubu & lost connection & First-9:04 & 19 & 6 & $42-174$ \\
\hline & Nichinan & Miyazaki-Shibushi & lost connection & First-9:06 & 14 & 3 & $13-33$ \\
\hline 30 January & Kitto & $\begin{array}{l}\text { Tanigashira Station } \\
*_{\text {safety equipment failure }}\end{array}$ & & $12: 37-14: 08$ & 2 & & \\
\hline 31 January & Kitto & Yoshimatsu-Miyakonojo & $\begin{array}{l}\text { switch failure } \\
\text { lost connection }\end{array}$ & 13:20-last & 17 & & \\
\hline 1 February & Kitto & Yoshimastu-Miyakonojo & $\begin{array}{l}\text { switch failure } \\
\text { lost connection }\end{array}$ & 12:24-last & 20 & & \\
\hline 2 February & Kitto & Yoshimatsu-Miyakonojo & $\begin{array}{l}\text { switch failure } \\
\text { lost connection }\end{array}$ & First-11:35 & 6 & & \\
\hline 5 February & Kitto & $\begin{array}{l}\text { Takaharu Station } \\
*_{\text {safety equipment failure }}\end{array}$ & lost connection & $6: 30-10: 15$ & 4 & & \\
\hline
\end{tabular}

nection was lost, and JR Kyushu therefore considered any tephra on the track sufficient to cancel services and begin cleaning operations. Whether tephra was wet or dry did not influence the occurrence of this impact.

In addition to the mechanical failure of track switches, accumulated tephra infiltrated gravel ballast under the tracks, reducing cushioning properties. This meant the ballast had to be replaced more frequently than usual, costing JR Kyushu as estimated 66 million JPY (850,000 USD). With an estimated $186 \mathrm{~km}$ of track impacted (Table 6), this equates to approximately 355,000 JPY (4,600 USD) per $\mathrm{km}$.

Prior to the eruption, JR Kyushu recently installed 360degree lights at crossings, which allowed drivers and others to see that the crossing was operating correctly. The system is activated by the train as it passes over a sensor. A backup sensor is installed on the carriages at a point before the crossing, although not on all crossings. Between 28 and 31 January this backup system was activated 39 times, suggesting that the initial system was not working effectively due to tephra accumulation.

6.8.2 Management JR Kyushu Railway Company has had considerable experience in dealing with tephra from frequent eruptions at Sakurajima volcano (Fig. 1). Several methods were previously implemented to deal with impacts from Sakurajima including using lower viscosity oil in track switches to avoid clogging and employing a sprinkler system to clean tephra from tracks on the Kagoshima route of the high speed Kyushu Shinkansen. However, tephra fall from Shinmoedake caused far greater problems for the company due to the large volume deposited over a short period of time. Company representatives reported to us that the scale of disruptions from this eruption was not expected; however, it was evident that through past experiences they were in an excellent position to manage the impacts.

An established protocol following eruptions from Sakurajima was that staff would be sent out to assess the switches and tracks each morning before the first train. If any tephra was on the tracks, then services would be cancelled until tracks could be cleaned. During the Shinmoedake eruption, this required a large number of staff and, in the early stages of the eruption, JR Kyushu was concerned about the sustainability of this approach as it was unclear how long the activity would continue.

Cleanup of the tracks and other critical areas was primarily carried out by JR staff members with additional staff brought in from Kagoshima, whilst contractors were used for secondary areas such as platforms. Tephra was usually blown or washed off the tracks-not collected. A carriage, developed from experiences with Sakurajima, was brought in which sprayed water onto the tracks to remove tephra. However, in secondary cleanup areas tephra was collected by the contractors and transported to the regular tephra dump locations. Tephra entering carriages meant that more frequent cleaning was required but no damage was reported. Larger problems were possibly avoided due to services typically not operating in ashy conditions.

Many tasks were outsourced to contractors including the replacement of ballast, dredging of tephra from ditches to the side of tracks, the dismantling and cleanup of track joints and switches, and removal of tephra from the surface of roads around 36 crossings (needing to be carried out twice). Other maintenance tasks conducted by JR Kyushu were increased, including the cleaning of tephra from rainfall gauges, electric substations and train components such as transformers and motors. 
An additional significant challenge identified by JR Kyushu was the need to disseminate information regarding delays and cancellations. It was uncertain how long the eruption would continue for and how much of the rail network would receive tephra fall requiring cancellation of services. Therefore, communicating this through various forms (e.g. media, websites, etc.) was a significant task that required sensitivity.

\section{Discussion}

During our first visit to the area, immediately following the main tephra falls of 26-27 January, residents and business owners were unsure about future eruptive activity and potential extended impacts and disruptions. Although the worst of the tephra had fallen at this time remobilised tephra was adding to the task of cleanup. In this largely agricultural area, farmers were not only concerned about the loss of current crops but also longer-term impacts to soil productivity. There were substantial concerns from residents and business owners that if the eruption was to continue producing high volumes of tephra, the ability to manage, clean and recover would be exceeded. Our second visit however, highlighted the resilience of the community and success of management strategies implemented. This effective recovery was aided by the relatively short eruption duration.

During the eruption crises, local government offices were organising a number of 'countermeasure' (mitigation) activities and tackling a broad range of arising issues that had not been anticipated. In particular, cleanup efforts were being delayed due to uncertainty regarding where tephra could be taken. However, organisations exhibited high levels of adaptive capacity to respond to the event, a contributing positive element being well-resourced and well-staffed municipal organisations. Many organisations (including agriculture, infrastructure and local government) were able to utilise regional and national networks to obtain information on tephra fall impacts and recovery strategies.

\subsection{Cleanup}

As highlighted here, a fall of just a few millimetres of tephra within an urban area requires the need for collection and disposal of large quantities of material in order to restore full functionality to road networks, airports, private properties and public places. Prompt cleanup reduces remobilisation of tephra, which minimises on-going disruptions and public health concerns. In the case discussed here, despite the relatively short eruption duration and efficient management, cleanup operations extended into September and beyond (Fig. 3). Residents and organisations in areas subjected to future tephra fall events may therefore expect many months of cleanup requirements, exacerbated by additional falls and remobilised material.

In extremely thick falls, tephra exceeding $100 \mathrm{~kg} / \mathrm{m}^{2}$ puts structures at risk of the onset of structural damage and collapse (Blong, 2003; Spence et al., 2005). During this relatively short eruption, these thicknesses were not exceeded in populated areas and only some lightly constructed, longspan livestock shelters and barns in Miike, proximal to the volcano (50-100 kg/m ${ }^{2}$ tephra accumulation), suffered structural damage due to tephra loading. However, it was desirable to remove lesser thicknesses of tephra from roofs to avoid the possibility of corrosion of roofing materials, blocking of gutters or ingress of tephra into the roof cavity (Blong, 1981). During the Shinmoedake eruption, residents and workers were responsible of removing tephra from roofs; although assistance was offered to the elderly and others requiring assistance. Although help was most often provided by family members and neighbours, an important consideration for future events is that both volunteer assistance and the efficient management of volunteers will be required.

A significant observation was the performance of the well sealed sewage and water supply networks, which were not cross connected and remained functional throughout the eruption and cleanup operations. The prompt and sustained cleanup of urban environments further reduced any disruption to these networks. In joint sewage-storm water networks, or where the sewage system has breaks, tephra has been known to enter the sewage system and block pipes and sumps, cause accelerated wear on motors and pumps, and seriously damage wastewater treatment plants (Wilson et al., 2012a); however, by eliminating ingestion this was successfully avoided. Likewise, water in the area is primarily sourced from deep wells and was therefore not exposed to or contaminated by tephra.

\subsection{Agriculture}

It is well established that agriculture is vulnerable to the physical and chemical effects of tephra, with impacts to vegetation, soil, animal health, human health and essential farm machinery and infrastructure all having been recorded (e.g. Cook et al., 1981; Blong, 1984; Neild et al., 1998; Cronin et al., 1998; Annen and Wagner, 2003; Ort et al., 2008; Wilson et al., 2011). A review by Wilson et al. (2011) identified a diverse range of agricultural impacts that are controlled by the physical and chemical characteristics of tephra, including the volume, rate and frequency of falls, environmental conditions pre- and post-tephra fall, mitigation measures employed and the pre-eruption condition of farms. During the andesitic Shinmoedake eruption (Suzuki et al., 2013), smothering, lodging, adherence blocking photosynthesis and abrasion of crops by tephra; coverage of soil and changes to soil properties; and loading and coverage of greenhouses were the most significant impacts.

Chemical impacts were seemingly less severe than physical damage, which we speculate was due to the eruption occurring when many crops were not at a sensitive stage or fields were in fallow. However, the high quality standards expected by Japanese consumers were an additional challenge for farmers. Acid damage was observed to affect leaf vegetables which reduced or voided product value, despite them being fit for consumption. When crops, such as spinach and tea, were intended for processing then this proceeded if chemical damage was not severe. Later, some damaged vegetables were purchased by an NGO and used for emergency food supply in areas affected by the 2011 Tohoku Earthquake and Tsunami (Miyazaki-Nichinichi Shimbun, 19 March 2011; Asahi Shimbun, 20 March 2011).

Our observation that physical impacts of tephra were dominant over chemical impacts are consistent with observations following various large silicic eruptions, such as the 1980 Mt. St. Helens (Cook et al., 1981), 1991 Hudson (Wil- 
son et al., 2011) and 2011 Puyehue Cordon-Caulle eruptions (Wilson et al., 2012a). In contrast, basaltic and andesitic tephras have lead to agricultural losses due to chemical effects, especially when there are high levels of available fluoride (Cronin et al., 2003). Notable examples include various eruptions of Hekla and the 1995 Ruapehu eruption (see Ayris and Delmelle, 2012). The lack of obvious serious chemical impacts from the Shinmoedake andesitic tephra highlights that the chemical hazard of tephras from individual eruptions is highly variable (see Ayris and Delmelle, 2012), and strongly dependent on the crops exposed and environmental conditions.

Here, standard soil science techniques were used by agricultural organisations to analyse the relevant properties of the tephra and to screen for elevated elemental concentrations. The results of these methodologies made for easy comparison to well known soil equivalents by agricultural officials and farmers. However, these methods do not facilitate comparison to other tephras, as more specialist analyses are typically used (Ayris and Delmelle, 2012). As the Shinmoedake tephra was far coarser $(0.5-10 \mathrm{~mm})$ than typical soils particle sizes $(<0.5 \mathrm{~mm})$, and tephras are known to potentially exhibit long-term, complex leaching of hazardous elements (e.g. Fluoride), a specialist tephra analysis protocol for agriculture may have been more useful to adequately evaluate the hazard (Ayris and Delmelle, 2012).

The extreme concerns of long term impacts to farm productivity at the time of the eruption were not realised, with only one crop rotation affected and soils relatively easily remediated through cultivation and supplementary fertilisation. Removal of tephra, deep cultivation and a focus on maintaining physical fertility (e.g. CEC and water holding capacity) appears to have successfully mitigated any medium to long-term effects of the tephra. Farmers were largely able to absorb the impacts of the eruption, with some government assistance, without having to alter their longterm farming practices.

Agricultural agencies stressed the importance of rapid identification of the affected area, damage assessment, and analysis of tephra characteristics. They also reported that collation and dissemination of information was a significant challenge; it was time consuming to collate current tephra chemical and textural characteristics with existing impact and management data. In addition, some farmers were not familiar with modern systems to receive information quickly; elderly farmers often had limited access to the internet.

Agricultural support and development organisations, such as JA, were instrumental in providing practical advice, informed by science. Whilst such organisations could collect information from their networks regarding impacts experienced and recovery strategies implemented during previous eruptions in Japan, the collation usually took several days. This was at a critical time when farmers required information quickly to reduce future losses. An aim for scientists and agricultural organisations should therefore be to collect, and present relevant data in an accessible way, so that it may be accessed quickly in the case of future tephra fall events. Information should be relevant to local agricultural and climatic conditions, easily accessible and pre- sented in the language best understood by agency workers and farmers.

\subsection{Electric power systems}

A review of the main impacts from tephra fall on electric power systems highlights: (1) supply outages from insulator flashover (unintentional electrical discharge around or over the surface of an insulator, which creates a fault on the circuit), (2) disruption of generation facilities, (3) controlled outages during tephra cleaning, (4) abrasion and corrosion of exposed equipment, and (5) line (conductor) breakage due to tephra loading (Wardman et al., 2012c). Of these impacts, insulator flashover is the most common. Electrical networks experienced relatively few disruptions during the Shinmoedake eruption. This was somewhat surprising given the thickness of the tephra fall, comparable conductivity to past flashover inducing tephras, and the extensive electrical network exposed. Wardman et al. (2012c) has suggested that $3 \mathrm{~mm}\left(3.3 \mathrm{~kg} / \mathrm{m}^{2}\right.$ in the case of Shinmoedake tephra) is a lower threshold for insulator flashover following volcanic ash contamination for HV power systems. However, no flashover activity occurred on any of the KEPC HV network, despite over $10 \mathrm{~km}$ of line receiving in excess of $10 \mathrm{~kg} / \mathrm{m}^{2}$ of tephra and over $17 \mathrm{~km}$ of line receiving in excess of $5 \mathrm{~kg} / \mathrm{m}^{2}$ (Table 5). Resilient design of jacketed insulators and over-insulation due to anthropogenic and coastal salt pollution in the area, along with a responsive tephra cleaning program for substations most likely contributed to mitigating tephra contamination and subsequent disruption. Additionally, the relatively coarse andesitic tephra appeared to have lower adherence potential to electrical components; the relatively dry conditions after the main tephra falls further contributed to the high tolerance of the network.

KEPC communicated that a key success was the development of an equipment cleaning system, so that when tephra contamination problems arose (e.g. leakage current) a rapid response could be made. KEPC had an up to date inventory of personnel and equipment, so were able to quickly request resources from other areas. The company identified that an analysis of tephra resistivity was important to guide cleaning and other mitigation actions and also highlighted the importance of maintaining a focus on the health and safety of staff.

\subsection{Rail network}

Very few published examples exist where tephra falls have caused the cancellation or disruption of train services. Those that do were summarised by Blong (1984) as follows: tephra of unknown thickness blocked rail lines for a period of seven days during the 1906 eruption of Vesuvio; during the May 1902 eruption of Soufrière, St. Vincent, a train was derailed in Bridgetown, Barbados as the result of only 5 $\mathrm{mm}$ of tephra; rail services in western Montana were disrupted by only 1-2 mm of tephra during the 1980 eruption of St. Helens due to reduced visibility and concerns regarding crew respiratory health; and from the same eruption, in Ritzville where tephra was up to $40 \mathrm{~mm}$ thick, cancellations and speed restrictions meant that full operation did not resume for 11 days; similar problems were observed in Missoula and Spokane.

In contrast to the above events, reduced visibility was not of large concern to train operations during the erup- 
tion of Shinmoedake. It was determined that is was safe for services to be operated in times of low visibility; although, since services were cancelled at any sign of tephra on tracks, few services operated during these conditions. The network was however affected by mechanical failure of track switches due to a build-up of tephra. The more modern train network also suffered due to losses of electrical contact between train wheels and track. JR Kyushu had previous experience in dealing with tephra falls from Sakurajima volcano and therefore had established management strategies that coped well during this crisis.

Although we focused here on impacts to the rail network, road and air transport networks were also affected. Several major roads were closed for periods of time due to reduced visibility, but a rapid and well coordinated cleanup operation mitigated the impacts. The eruption also caused disruption to the aviation sector, particularly for Miyazaki airport, which experienced a $22 \%$ reduction in passenger numbers following several closures and, possibly, safety concerns of tourists.

\section{Conclusions}

Two visits were made to the areas affected by tephra from the 2011 Shinmoedake eruption with the aim to assess the impacts of tephra fall on both a major urban area and agricultural land, while focusing on four key sectors. Valuable lessons from this event will add to the growing body of evidence detailing impacts from diverse eruptions and will help to inform the future management of tephra fall events both in Japan and internationally.

The cleanup of tephra was time consuming, physically demanding and costly and involved most residents and businesses. Limited data was available for calculating the costs of cleanup; however, when considering the collection of tephra from urban areas, we estimate a cost of 23 JPY (0.30 USD) per $\mathrm{kg}$ to the local government. Road cleanup operations were estimated to cost approximately 50,300 JPY (650 USD) per km or $17 \mathrm{JPY}$ (0.22 USD) per kg.

Large initial impacts were felt by the agricultural sector with smothering, loading and abrasion of crops, soils and greenhouses. However, extreme concerns at the time of the eruption were not realised and long-term farming operations were not substantially affected. There were few disruptions to electrical networks due to resilient insulator design, a successful cleaning program, relatively coarse tephra and dry conditions. Cancellations and delays occurred on three rail lines resulting primarily from mechanical failure of track switches and loss of electrical contact between train wheels and tracks.

Generally, residents and organisations exhibited high levels of adaptive capacity in response to the event. Regional and national networks were critical in obtaining information on past events and associated management and recovery strategies. The relatively short eruption duration contributed to a fast recovery, which was also aided by well resourced and coordinated organisations and resilient infrastructure networks.

Acknowledgments. We thank the Japanese scientific community for their support during our investigation. In particular we are grateful for the advice offered by Emeritus Professor Shigeo Aramaki (Yamanashi Institute of Environmental Sciences), Professor Setsuya Nakada (Earthquake Research Institute, University of Tokyo), Dr. Kazutaka Mannen (Hot Springs Research Institute of Kanagawa Prefecture), Dr. Yasuhiro Ishimine (RIKEN, Institute of Physical and Chemical Research), Ms. Kana Miyashita and Dr. Takuro Kimura (GENSAI, Organisation for Disaster Reduction and Reconstruction Support) and Professor Toshiaki Hasenaka (Graduate School of Science and Technology, Kumamoto University). Dr. Keping Chen (Risk Frontiers, Macquarie University) carried out the analysis of Landsat imagery and identification of urban and agricultural land-usage; we thank him for his time and expertise. Johnny Wardman (University of Cantebury) analysed the ESDD/NSDD tephras and prepared Fig. 6. Dr. Ishimine and an anonymous reviewer provided comments that greatly improved the manuscript and Dr. Deanne Bird and Professor John McAneney provided thorough early reviews. Above all we must thank the residents, farmers, workers and business owners of Miyakonojo, Takaharu, Nichinan and Kirishima who welcomed us and were happy to take the time to share their experiences during a very difficult and uncertain time. We particularly wish to thank the local governments of Miyakonojo City, Takaharu Town and Kirishima City as well as the Agricultural Improvement and Promotion Centre of Kitamorokata Region, JA Miyakonojo, Miyazaki Prefecture Livestock Public Corporation, JR Kyushu, Kyushu Electric Power Company and Kirishima Kokusai Hotel, who provided much of the information on impacts and countermeasures presented here.

\section{References}

Agriculture Improvement and Promotion Centre, Cultivation schedule for processing vegetables, Internal Report, 2011 (in Japanese).

AIST (National Institute of Advanced Industrial Science and Technology), Isomass contours that describes ash accumulation from Kirishimayama-Shinmoedake eruption between 26 and 27 January, 2011, http://www.aist.go.jp/ aist_j/press_release/pr2011/pr20110201_2/pr20110201_2.html, accessed: 16 April 2013, 2011 (in Japanese).

Annen, C. and J. Wagner, The impact of volcanic eruptions during the 1990s, Nat. Haz. Rev., 4(4), 169-175, 2003.

Architectural Institute of Japan, Preliminary Reconnaissance Report of the 2011 Tohoku-Chiho Taiheiyo-Oki Earthquake, 460 pp., Springer Verlag, Japan, 2012.

Ayris, P. M. and P. Delmelle, The immediate environmental effects of tephra emission, Bull. Volcanol., 74(9), 1905-1936, 2012.

Bird, D. K. and G. Gísladóttir, Residents' attitudes and behaviour before and after the 2010 Eyjafjallajökull eruptions-a case study from southern Iceland, Bull. Volcanol., 74(6), 1263-1279, 2012.

Bird, D., D. King, K. Haynes, P. Box, T. Okada, and K. Nairn, Impact of the 2010/11 floods and the factors that inhibit and enable household adaptation strategies, 160 pp., Report for the National Climate Change Adaptation Research Facility, Gold Coast, Australia, 2013.

Blong, R. J., Some effects of tephra fall on buildings, in Tephra Studies, edited by S. Self and R. S. J. Sparks, 405-420, D. Reidel Publishing Company, Dordrecht, The Netherlands, 1981.

Blong, R. J., Volcanic Hazards: A Sourcebook on the Effects of Eruptions, 424 pp., Academic Press, Australia, 1984.

Blong, R. J., Building damage in Rabaul, Papua New Guinea, 1994, Bull. Volcanol., 65, 43-54, 2003.

Blong, R. J. and C. McKee, The Rabaul Eruption 1994: Destruction of a Town, 52 pp., Natural Hazards Research Centre, Sydney, 1995.

Boughton, G. N., D. J. Henderson, J. G. Ginger, J. D. Holmes, G. R. Walker, C. J. Leitch, L. R. Somerville, U. Frye, N. C. Jayasinghe, and P. Y. Kim, Tropical Cyclone Yasi: Structural damage to buildings, 127 pp., Cyclone Testing Station, James Cook University, Technical Report No. 57, 2011.

Broom, S. J., Characterisation of 'synthetic ash' for quantitative testing of critical infrastructure components with a focus on roofing fragility, B.Sc. (Honours) dissertation, University of Canterbury, 2010.

Cabinet Office, Damage situation caused by the eruption of Kirishimayama (Shinmoedake), http://www.bousai.go.jp/updates/pdf/ 110307kirishimasaigaizyoukyou13.pdf, accessed: 16 April 2013, 2011 (in Japanese).

City of Miyakonojo, Profile of Miyakonojo, http://cms.city.miyakonojo. 
miyazaki.jp/display.php?cont=120905131042, accessed: 16 April 2013, 2013.

Cook, R. J., J. C. Barron, R. I. Papendick, and G. J. Williams, Impact of agriculture of the Mount St. Helens eruptions, Science, 211, 16-22, 1981.

Cronin, S. J., M. J. Hedley, V. E. Neall, and R. G. Smith, Agronomic impact of tephra fallout from the 1995 and 1996 Ruapehu Volcano eruptions, New Zealand, Environ. Geol., 34(1), 21-30, 1998.

Cronin, S. J., V. E. Neall, J. A. Lecointre, M. J. Hedley, and P. Loganathan, Environmental hazards of fluoride in volcanic ash: A case study from Ruapehu volcano, New Zealand, J. Volcanol. Geotherm. Res., 121, 271291, 2003.

Cubrinovski, M., R. A. Green, and L. Wotherspoon, Geotechnical Reconnaissance of the 2011 Christchurch, New Zealand earthquake, GEER Association Report No. GEER-027, 2011.

Department of Agricultural Policy and Fisheries of Miyazaki Prefecture, Summary of damage related to agriculture and fishery due to the volcanic activity of the Shinmoedake (as of the 31st of March), Internal Municipal Report, 2011 (in Japanese).

EERI (Earthquake Engineering Research Institute), The March 11, 2011, Great East Japan (Tohoku) Earthquake and Tsunami: Societal Dimensions, 23 pp., EERI Special Earthquake Report, 2011.

FEMA (Federal Emergency Management Authority), Hurricane Katrina in the Gulf Coast, Mitigation Assessment Team Report: Building Performance Observations, Recommendations, and Technical Guidance, FEMA 549, 2006.

Folsom, M. M., Tephra on range and forest lands of eastern Washington: Local erosion and redeposition, in Mount St. Helens: Five Years Later, edited by S. A. C. Keller, pp. 116-119, Eastern Washington University Press, 1986.

Fukuoka District Meteorological Observatory Volcano Monitoring and Information Centre and Kagoshima Regional Meteorological Observatory, Reporting Material of Volcanic Activity at Kirishimayama February 2011, http://www.seisvol.kishou.go.jp/tokyo/STOCK/monthly_vact_doc/fukuoka/11m02/505_11m02.pdf, accessed 16 April 2013, 2011 (in Japanese).

Hasenaka, T., H. E. Wibowo, I. A. Kurniawan, C. Connor, L. Connor, K. Kiyosugi, and C. Bonadonna, Tephra fallout model and grain size distribution of Shinmoe-Dake tephra, 2011 eruption of Kirishima volcano. Japan Geoscience Union Meeting 2011, Makuhari, Chiba, Japan, May 22-27 2011, SVC070, p. 18, 2011.

Haynes, K., J. Barclay, and N. F. Pidgeon, Whose reality counts? Factors affecting the perception of volcanic risk, J. Volcanol. Geotherm. Res., 172(3-4), 59-272, 2008.

Horwell, C. J. and P. J. Baxter, The respiratory health hazards of volcanic ash: A review for volcanic risk mitigation, Bull. Volcanol., 69, 1-24, 2006.

IEC (International Electrotechnical Commission), Standard 60815, Selection and dimensioning of high voltage insulators intended for use in polluted conditions, 108 pp., IEC/TS 60815, 2008.

IEEE (Institute of Electrical and Electronics Engineers working group on insulator contamination), Application of insulators in a contaminated environment, IEEE Transactions on Power Apparatus and Systems, 98(5), 1676-1695, 1979.

Imura, R., Eruptive history of Kirishima Volcano during the past 22,000 years, Geogr. Rep. Tokyo Metro. Univ., 27, 71-89, 1992.

Imura, R. and T. Kobayashi, Eruption of Shinmoedake Volcano, Kirishima Volcano Group, in the Last 300 Years, Bull. Volcanol. Soc. Jpn., 2, 135148, 1991 (in Japanese).

Imura, $\mathrm{R}$ and $\mathrm{T}$. Kobayashi, Geological map of Kirishima Volcano (1:50,000), Geological Survey of Japan, 2001.

Jenkins, S., J.-C. Komorowski, P. J. Baxter, R. Spence, A. Picquout, F. Lavigne, and Surono, The Merapi 2010 eruption: An interdisciplinary impact assessment methodology for studying pyroclastic density current dynamics, J. Volcanol. Geotherm. Res., doi:10.1016/j.jvolgeores.2013.02.012, 2013.

JMA (Japan Meteorological Agency), Japan regional climate data, http://www.jma.go.jp/jma/indexe.html, accessed 25 October 2012, 2012.

Johnston, D. M., B. F. Houghton, V. E. Neall, K. R. Ronan, and D. Paton, Impacts of the 1945 and 1995-1996 Ruapehu eruptions, New Zealand: An example of increasing societal vulnerability, Geol. Soc. Am. Bull., 112(5), 720-726, 2000.

Kagoshima Regional Meteorological Observatory, Investigation of damage caused by shockwaves associated with Kirishimayama (Shinmoedake) eruption, 9 March 2011, http://www.jma-net.go.jp/ kagoshima/bousai/vol/kushin_chousa_kago20110309_2.pdf, accessed: 14 May 2013, 2011 (in Japanese).

Leonard, G. S., D. M. Johnston, S. Williams, J. Cole, K. Finnis, and $\mathrm{S}$. Barnard, Impacts and management of recent volcanic eruptions in Ecuador: Lessons for New Zealand, GNS Science Report 2005/20, 2005.

Magill, C. R. and T. Okada, Preliminary investigation of the Impacts of the 2011 Shinmoedake eruption, 31 pp., Risk Frontiers Report, 2011.

Ministry of Agriculture, Forestry and Fisheries, 2008 agricultural output, Statistics of Agriculture, Forestry and Fisheries, http://www.maff.go.jp/j/tokei/kouhyou/nougyou_sansyutu/ pdf/sansyutu_zenkoku_09.pdf, accessed: 16 April 2013, 2010 (in Japanese).

Ministry of Land, Infrastructure, Transport and Tourism, ShinmoedakeMeasures taken after the eruption and plans for the future, Internal Report, 2011 (in Japanese).

Miyabuchi, Y., D. Hanada, H. Niimi, and T. Kobayashi, Stratigraphy, grain-size and component characteristics of the 2011 Shinmoedake eruption deposits, Kirishima Volcano, Japan, J. Volcanol. Geotherm. Res., doi:10.1016/j.jvolgeores.2013.03.027, 2013.

Miyazaki Airport Building Co. Ltd., The 49th term business report1 April 2010 to 31 March 2011, http://www.miyazaki-airport. co.jp/company/pdf/houkoku49.pdf, accessed: 16 April 2013, 2011 (in Japanese).

Miyazaki Prefecture, Agriculture in Miyazaki, http://www.pref.miyazaki. lg.jp/nousei/nouson/nn/miyanou.html, accessed: 16 April 2013, 2010 (in Japanese).

Neild, J., P. O'Flaherty, P. Hedley, R. Underwood, D. Johnston, B. Christenson, and P. Brown, Impact of a Volcanic Eruption on Agriculture and Forestry in New Zealand, 101 pp., MAF Policy Technical Paper, 99/2, 1998.

Ort, M. H., M. D. Elson, K. C. Anderson, W. A. Duffield, J. A. Hooten, D. E. Champion, and G. Waring, Effects of scoria-cone eruptions upon nearby human communities, Geol. Soc. Am. Bull., 120(3/4), 476-486, 2008.

Reycraft, R. M. and G. Bawden, Introduction, in Environmental Disaster and the Archaeology of Human Response, edited by G. Bawden and R. M. Reycraft, 1-10, Maxwell Museum of Anthropology, Anthropological Papers, No. 7, Albuquerque, 2000.

Siebert, L. and T. Simkin, Volcanoes of the World: An illustrated catalogue of Holocene volcanoes and their eruptions, in Smithsonian Institution, Global Volcanism Program Digital Information Series GVP-3, http://www.volcano.si.edu/world/, 2002-.

Spence, R., I. Kelman, P. J. Baxter, G. Zuccaro, and S. Petrazzuoli, Residential building and occupant vulnerability to tephra fall, Nat. Haz. Earth Sys., 5, 477-494, 2005.

Spence, R., E. So, S. Jenkins, A. Coburn, and S. Ruffle, Chapter 5, A global earthquake building damage and casualty database, in Human Casualties in Earthquakes, Progress in Modelling and Mitigation, edited by R. Spence, E. So, and C. Scawthorn, pp. 65-79, Advances in Natural and Technological Hazards Research 29, Springer Science +Business Media B.V., 2011.

Suzuki, Y., A. Yasuda, N. Hokanishi, T. Kaneko, S. Nakada, and T. Fujii, Syneruptive deep magma transfer and shallow magma remobilization during the 2011 eruption of Shinmoe-dake, Japan-Constraints from melt inclusions and phase equilibria experiments, J. Volcanol. Geotherm. Res., 257, 184-204, doi:10.1016/j.jvolgeores.2013.03.017, 2013.

Takaharu Town, Disaster countermeasures and future challenges in Takaharu Town, Internal municipal report, 2011a (in Japanese).

Takaharu Town, List of Shinmoedake projects, Internal municipal report, 2011 b (in Japanese).

Takaharu Town, Takaharu Town Disaster Management Office announcement no. 55, 25 March 2011, http://www.town.takaharu.lg.jp/modules/ d3downloads/index.php?page $=$ singlefile $\&$ cid $=23 \&$ lid $=265$, accessed 14 May 2013, 2011c (in Japanese).

Wardman, J., V. Sword-Daniels, C. Stewart, and T. Wilson, Impact assessment of the May 2010 eruption of Pacaya volcano, Guatemala, 90 pp., GNS Science Report 2012/09, 2012a.

Wardman, J. B., T. M. Wilson, P. S. Bodger, J. W. Cole, and D. M. Johnston, Investigating the electrical conductivity of volcanic ash and its effect on HV power systems, Phys. Chem. Earth., 45-46, 128-145, 2012b.

Wardman, J. B., T. M. Wilson, P. S. Bodger, J. W. Cole, and C. Stewart, Potential impacts from tephra fall to electric power systems: A review and mitigation strategies, Bull. Volcanol., 74, 2221-2241, 2012c.

Wardman, J., T. Wilson, and P. Bodger, Volcanic ash contamination: Lim- 
itations of the standard ESSD method for classifying pollution severity, IEEE Transactions on Dielectrics and Electrical Insulation, 20(2), 414420, 2013.

Wilson, T. M. and J. W. Cole, Potential impacts of ash eruptions on dairy farms from a study of the effects on a farm in eastern Bay of Plenty, New Zealand; implications for hazard analysis, Nat. Haz., 43(1), 103128, 2007.

Wilson, T., G. Kaye, C. Stewart, and J. Cole, Impacts of the 2006 eruption of Merapi volcano, Indonesia, on agriculture and infrastructure, $69 \mathrm{pp}$., GNS Science Report 2007/07, 2007.

Wilson, T., J. Cole, S. Cronin, D. Johnston, and C. Stewart, Impacts on agriculture following the 1991 eruption of Vulcan Hudson, Patagonia: Lessons for recovery, Nat. Haz., 57(2), 185-212, 2011.

Wilson, T., C. Stewart, H. Bickerton, P. Baxter, V. Outes, G. Villarosa, and
E. Rovere, Impacts of the June 2011 Puyehue-Cordon Caulle volcanic complex eruption on urban infrastructure, agriculture and public health, 88 pp., GNS Science Report 2012/20, 2012a.

Wilson, T. M., C. Stewart, V. Sword-Daniels, G. S. Leonard, D. M. Johnston, J. W. Cole, J. B. Wardman, G. Wilson, and S. Barnard, Volcanic ash impacts on critical infrastructure, Phys. Chem. Earth., 45-46, 5-23, 2012b.

Witham, C. S., C. Oppenheimer, and C. J. Horwell, Volcanic ash-leachates: A review and recommendations for sampling methods, J. Volcanol. Geotherm. Res., 141, 299-326, 2005.

C. Magill (e-mail: christina.magill@mq.edu.au), T. Wilson, and T. Okada 